Article

\title{
Landscape Fire, Biodiversity Decline and a Rapidly Changing Milieu: A Microcosm of Global Issues in an Australian Biodiversity Hotspot
}

A. Malcolm Gill ${ }^{1, *}$, David J. McKenna ${ }^{2}$ and Michael A. Wouters ${ }^{2}$

1 Fenner School of Environment and Society, Australian National University, Canberra, ACT 0200, Australia

2 South Australian Department of Environment, Water and Natural Resources, GPO Box 1047, Adelaide, SA 5001, Australia; E-Mails: David.McKenna3@sa.gov.au (D.J.M.);

Mike.Wouters@sa.gov.au (M.A.W.)

* Author to whom correspondence should be addressed; E-Mail: malcolm.gill@anu.edu.au; Tel.: +61-2-6125-0843.

Received: 25 June 2014; in revised form: 27 August 2014 / Accepted: 28 August 2014 /

Published: 9 September 2014

\begin{abstract}
The Adelaide-Mt Lofty Region of South Australia is an exemplar, in microcosm, of the issues confronting biodiversity conservation in a world of increasing population and a drying, fire-prone environment. At just $0.1 \%$ of Australia's terrestrial land mass, this area is largely peninsular and oriented along a spine of ranges to $730-\mathrm{m}$ elevation. Annual average rainfall varies from over $1100 \mathrm{~mm}$ in the hills to less than $500 \mathrm{~mm}$ on the plains in the north. The original vegetation varied from grasslands to shrublands to grassy and shrubby woodlands to forests, but now includes a major capital city and a mixed farming hinterland. Biodiversity in the region is in decline, and many species' extinctions have been recorded. With increasing population and a drying climate, fire antecedents, like ignition and fire danger, are predicted to increase the area burned in the wetter regions, but such predictions may be offset by increasing the fire protection of the expanding population and their economic and social assets. While the existing system of many small reserves will remain the backbone of biodiversity conservation in the region, wider recognition of the all-tenure, whole-of-landscape, whole-of-community approach to biodiversity conservation and fire management is needed if the probability of further extinctions is to be reduced.
\end{abstract}


Keywords: conservation reserve; population; climate change; fragmentation; land systems; Adelaide-Mount Lofty

\section{Introduction}

Global biodiversity is considered to be in its sixth main extinction event in the Earth's geological and contemporary history, but the present episode is due to human activity [1]. Australia has the dubious distinction of leading the world in the number of mammal extinctions [2]. It is considered that more than 60 species of vascular plants are extinct, and 1180 threatened, at a national level [3]. Local extinctions have been common in some places, such as in cities, while at a regional level, the extinction rate is in between that of city areas and the continent. At each of these geographical scales, in Australia and around the world, reactions to the decline of biodiversity have included attempts to reverse adverse trends by: increasing the number and area of official conservation reserves; breeding and translocating native animals; seeking more control over feral animals, exotic diseases and weeds; storing seeds in artificial seed-banks; replanting with indigenous species; promoting positive habitat change, such as by installing nest boxes; establishing connectivity across landscapes ("nature links", "bio-links", "biodiversity corridors", "conservation connectivity areas") (e.g., [4]) and applying appropriate fire regimes (sensu [5,6]).

Fires occurrences and their impact on economic, social and environmental assets around the world are changing rapidly due to changing fuels, climates and ignition sources, e.g., [7]. Changing fuels are predicted, in part, due to increasing atmospheric carbon dioxide levels (now at their highest in a million years [8]), but also to changed land uses, changed ecosystems and changed management of public land. Changing climates have various effects on different landscapes and, consequently, on different fire intervals, according to where, on the spectrum of the fire interval and climate, the site occurs: if a semi-arid environment is becoming wetter, the fire interval can be expected to shorten; if a moist climate is becoming wetter, the average fire interval can become longer, e.g., [9]. Most of Australia is drying and warming [10], a trend exemplified by its record high temperature, its "Angry Summer", in 2012-2013 [11].

In many, perhaps all, fire-prone regions of the world, most fires are caused by people, e.g., in Australia [12], China [13] and Spain [14], and often ignited along roads or associated with higher population density generally, e.g., in Australia [15], South Wales [16], southern France [17] and the USA $[18,19]$. Ignitions may be due to carelessness, but also due to clashing electrical conductors in power-lines and arson, for example; so, it can be expected that as population burgeons, the numbers of ignitions will also increase. Prescribed fires may also increase in number and area (note, later, the recent increasing trend in the study area, as shown in Figure 5b), affecting the contemporary unplanned fire regime to various extents, depending on the environmental context and previous management.

Attention in this paper is focussed on the effects of changing fire circumstances on indigenous biodiversity (i.e., in situ biodiversity), particularly in conservation reserves, but the fire-management responses to changing fire and fuel circumstances in reserves will be affected by the changing circumstances in the wider landscape, by the budgetary responses of governments and by community 
perspectives. Landscapes surrounding reserves may hold assets with sensitivities to fire or smoke regimes, yet species within the biodiversity asset are adapted to selected fire regimes. Needless to say, the situation is complex and involves many stakeholders [20].

In this paper, we examine the interactions between fire regimes and biodiversity with reference to the major worldwide challenges of climate change and rapidly increasing human populations in fragmented landscapes. We use the landscapes of the Adelaide-Mt Lofty Region, South Australia, (AMLR) as our primary exemplar. The area is part of one of 15 Australian biodiversity hotspots identified by the Australian Government's Department of the Environment [21]. It includes a sub-region, which is a "potential climatic refugium" under climate change scenarios [22]. In particular, we address biodiversity conservation in relation to human density impacts, the effects of rural land use and the social importance of unplanned ("wild") fires, as well as fire-regime effects generally. We set the scene for a discussion of future likelihoods with respect to biodiversity and fire issues in an all-tenure, whole-of-landscape [23], whole-of-community manner by considering five situations that exemplify the main issues in the study area. Framing and illustrating the complex issues around the rapidly changing biodiversity-fire-climate-population interaction is challenging, but there is a compelling case to address them if biological conservation in fire-prone areas is to be successful.

The five situations prominent in particular locations in the AMLR that represent similar issues found in national and international arenas are those in which:

(i) people are the dominant influence on fires and biodiversity, i.e., in the city of Adelaide and its suburbs on the coastal plain,

(ii) agriculture is prominent, in grasslands and grassy woodlands, and tree-species regeneration is a conservation issue;

(iii) the hilly topography has major effects on bushfire behaviour and can have serious consequences for social and economic assets, including human fatalities;

(iv) swamp-vegetation is rare and "critically endangered" [24], but little conserved, and fires there can be in peat, a fuel of considerable significance in tropical, as well as temperate zones; and,

(v) threatened species, such as orchids and bandicoots, particularly in shrub and shrub woodland communities face inappropriate fire regimes and other threats.

The examples we draw upon lead to an understanding of the challenges of climate change, population growth and biodiversity conservation in fire-prone environments. They reveal a lack of knowledge of fire regime-biodiversity interactions in many areas and implicitly indicate the increasing expenditure needed for effective management in a rapidly changing world.

\section{The Study Area}

Our AMLR study area of 781,000 ha (Figure 1) is identical to that of Willson and Bignall [25]. Its cultural focal point, Adelaide, is the capital city of South Australia, a city spread along the coast of St. Vincent's Gulf. Greater Adelaide has a population of over one and a quarter million [26]. Its growth since first settlement by Europeans in 1836 [27] on land occupied by Aboriginal people is a major factor in what has happened historically to the surrounding landscape and what will continue to happen in the future. 
Figure 1. The Adelaide-Mt Lofty Region Study Area (bounded by the red line). The "frequency of burn/fire" is the number of times fires - prescribed "burns" or unplanned fires - have been recorded since 1951-1952 and up to 2013-2014. Records may be incomplete, particularly for small fires and fires on private land.

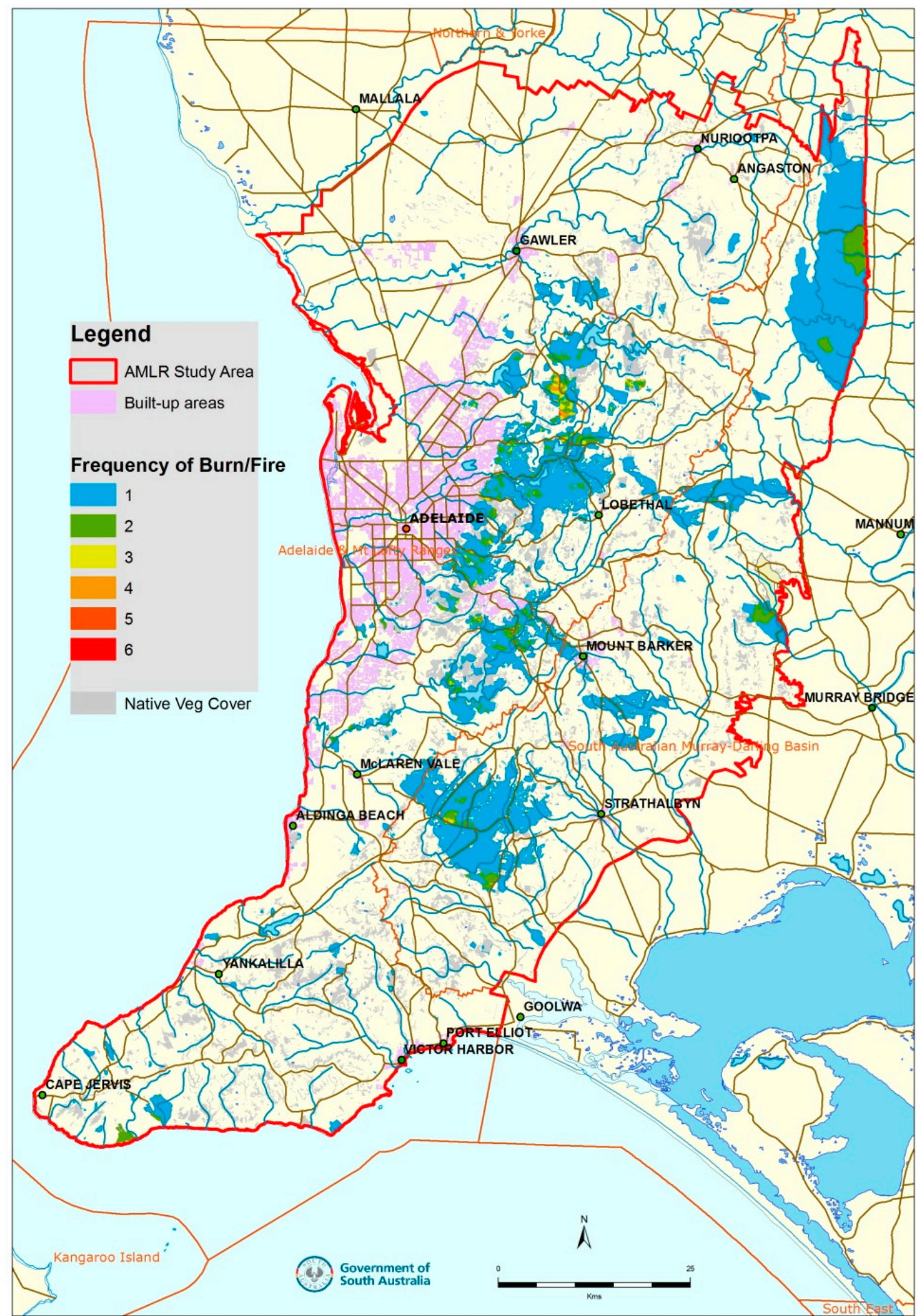


The topographic spine of the region is a line of hills and low mountains running more or less north-south, known as the Mt Lofty Ranges. These ranges extend south through the Fleurieu Peninsula, one of three south-pointing peninsulas in the wider region, the other two being the Yorke and Eyre Peninsulas to the west. Slopes can be steep in parts along the entire length of the Ranges.

The AMLR is characterised by a Mediterranean climate of hot dry summers and cool wet winters. Average annual rainfalls vary from about $400 \mathrm{~mm} / \mathrm{yr}$ to over $1100 \mathrm{~mm} / \mathrm{yr}$ [28]. The vegetation at settlement varied from eucalypt forests and woodlands to mallee and other types of shrublands, as well as coastal types [25].

Today, grain production is a feature of the northern areas, dairying and irrigated pasture in the south; major wine-grape growing regions are a feature; and orchards are common in the Adelaide Hills [29]. There are plantations of pine (Pinus radiata) and eucalypts (such as Eucalyptus globulus) in the area. Mixed farming in the Adelaide Hills is illustrated in Figure 2.

Figure 2. Mixed farming is typical of the Adelaide Hills region. Note the forest remnants in the background (Photo: A. Malcolm Gill).

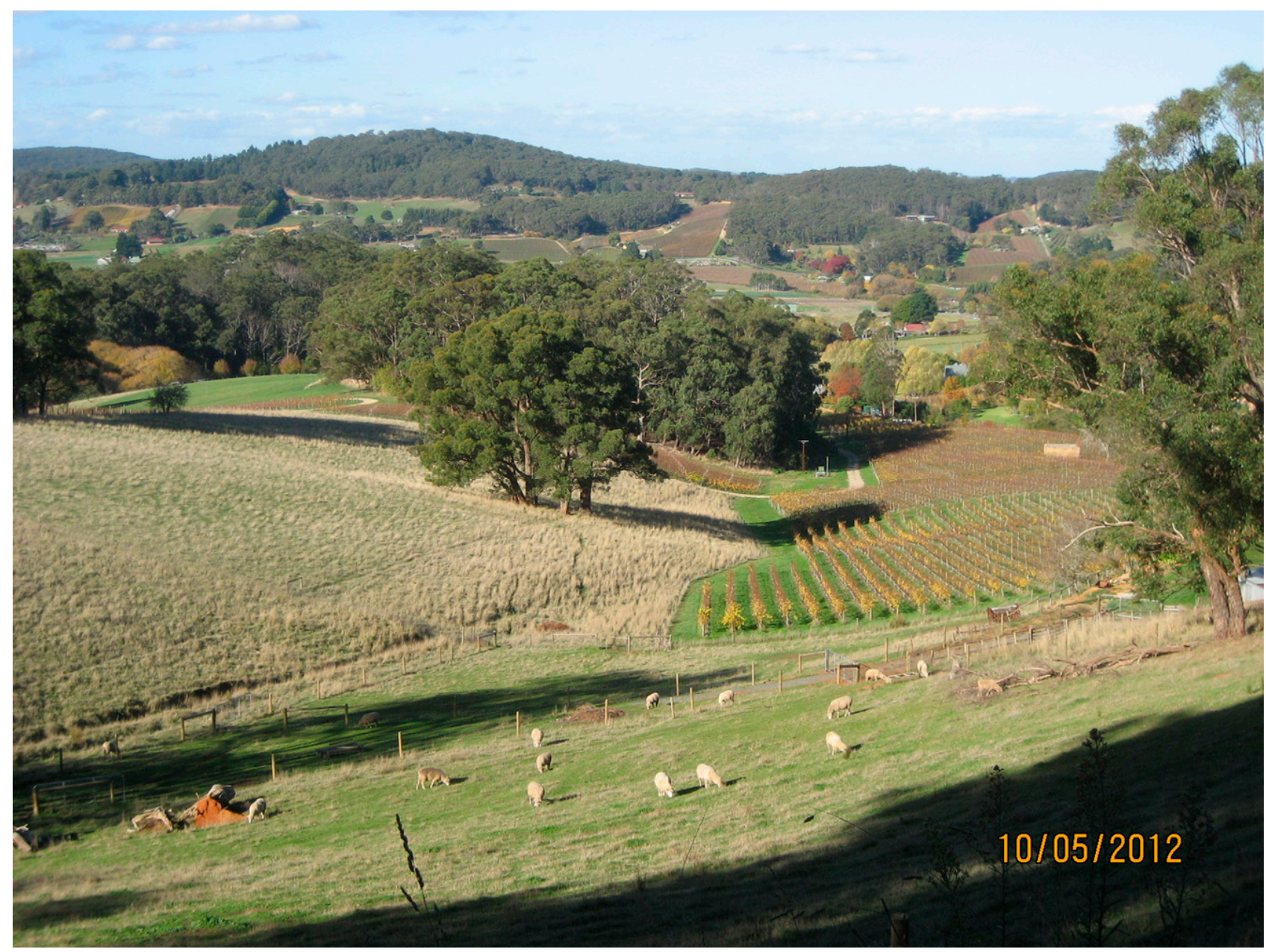

Conservation reserves are the backbone of biodiversity conservation in the region. The conservation-reserve system consists of a few, moderately-sized, reserves on public land supplemented by a large number of generally smaller areas on private land-“Heritage Agreement" sites (Figure 3a,b). The system evolved and grew from reserves selected largely for their amenity to one 
with conservation as the prime purpose, creating a system with large reserves in the more arid regions of South Australia and many small reserves in more populated areas [30]. Outside such jurisdictions are a large number of remnant vegetation patches (Figure 3c) and more-altered landscapes that have some biodiversity conservation value.

Figure 3. Frequency distributions of areas of: (a) official conservation reserves; (b) "Heritage Agreement" sites; and (c) remnant vegetation patches. Note the order-of-magnitude change of scale for the frequency of remnant patches.

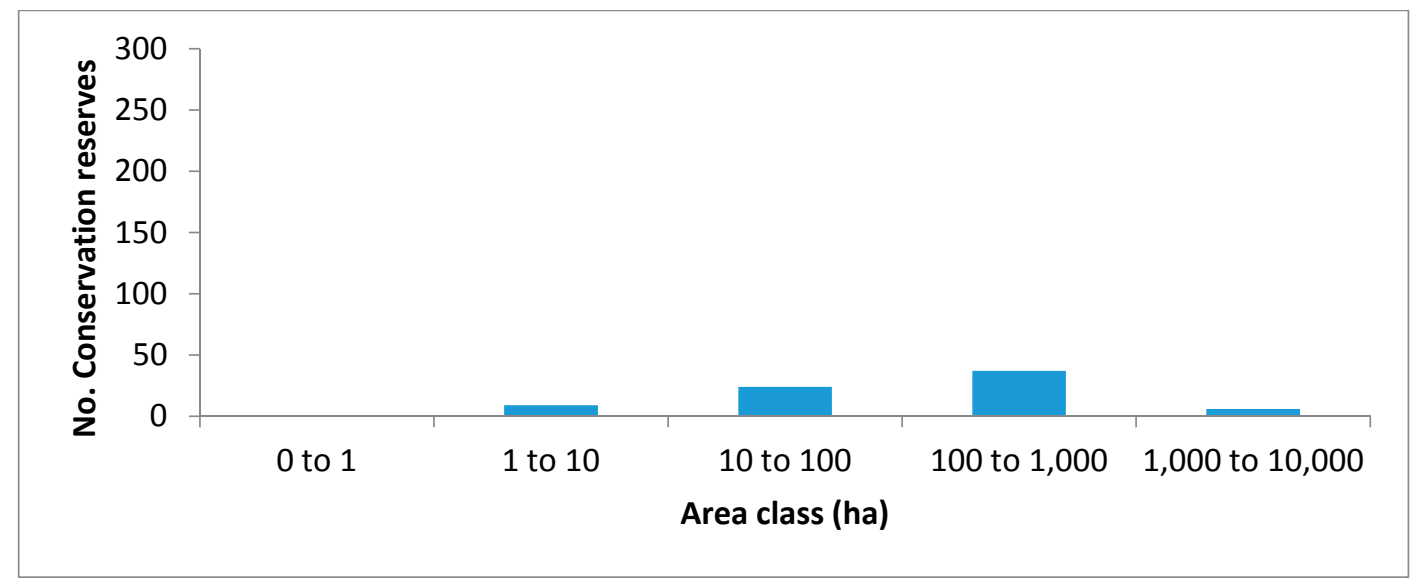

(a)

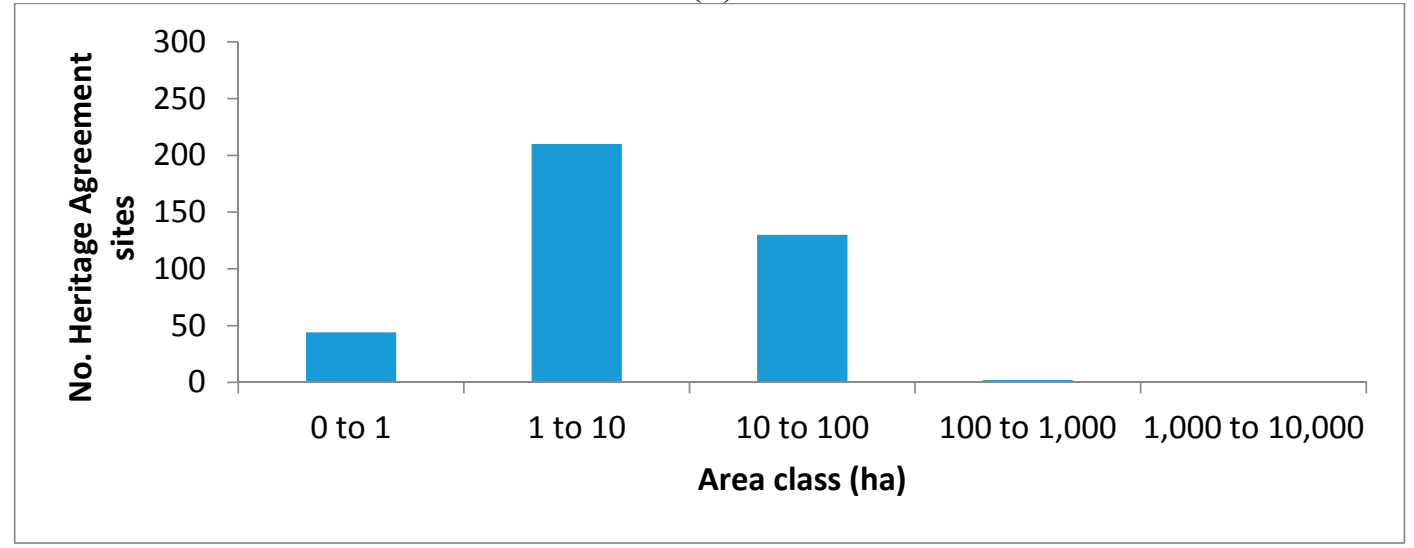

(b)

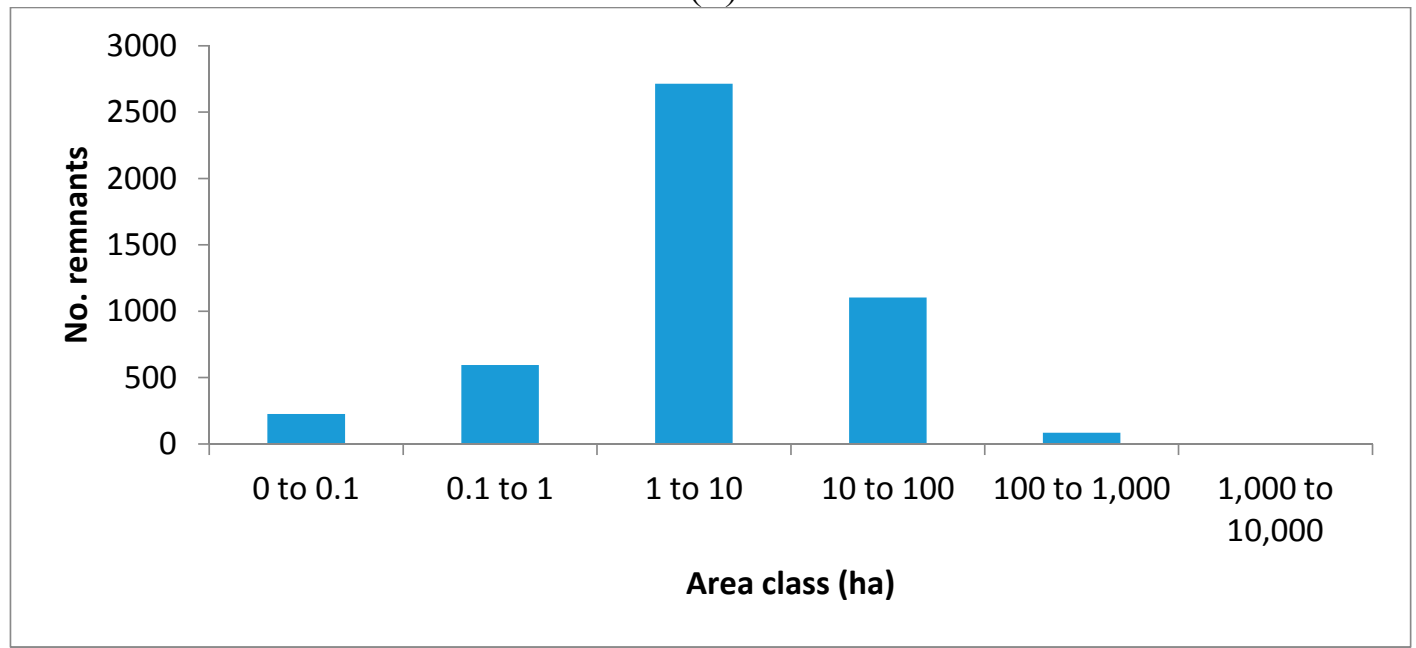

(c) 
Figure 4. The growth of Adelaide, South Australia, from the time of settlement, 1836 (courtesy of Simeon Telfer [31]). Note the green belt around the more-or-less rectangular city centre in each map. NPWSA: National Parks and Wildlife Service Act.
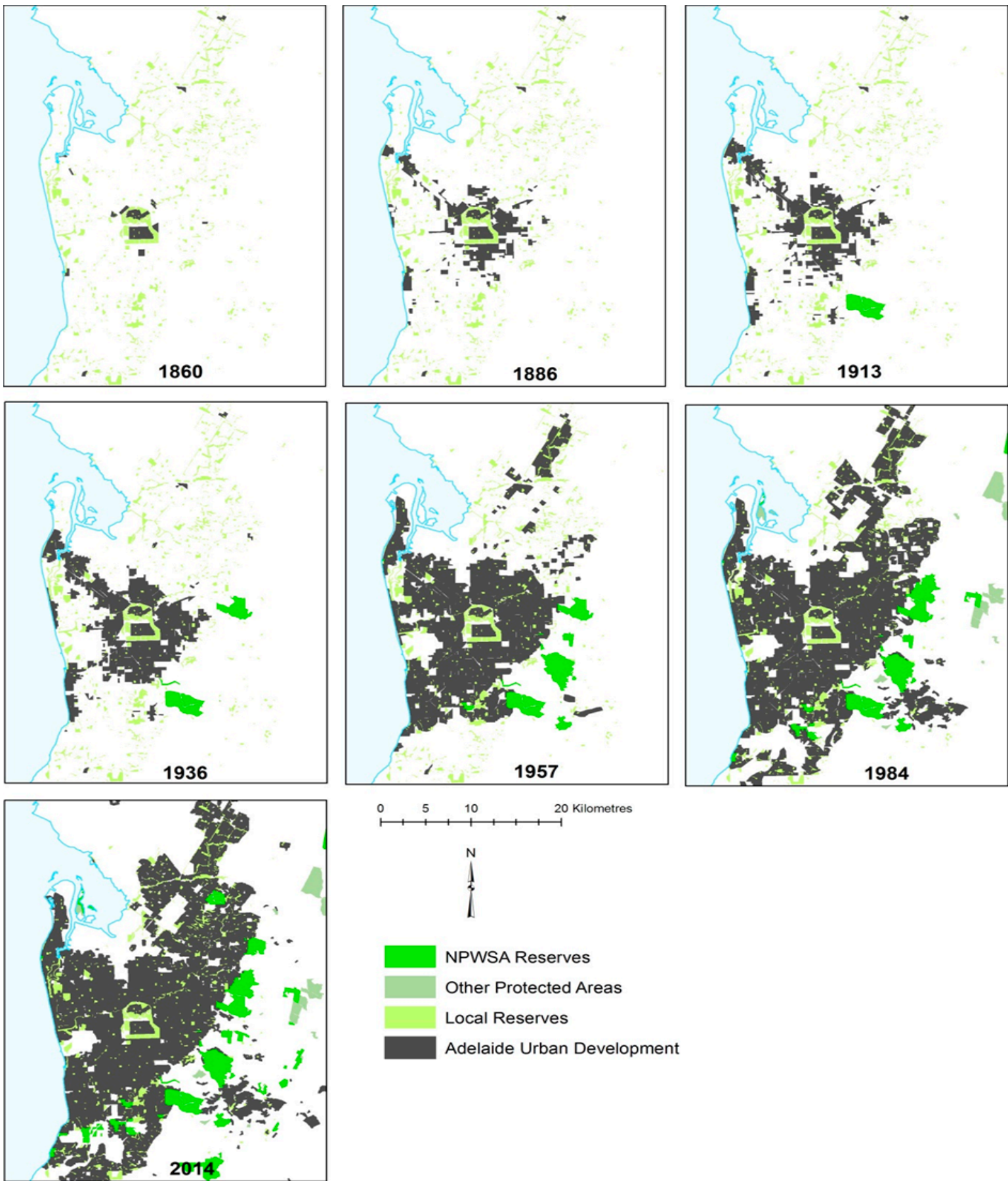

Greater Adelaide now encompasses some of the reserves and borders on others (e.g., for the change, see the maps from 1880 to 1965 in [32] and Figure 4). Changes in the proximity of reserves to high population density are likely to continue as the population expands to "between 1.7 million and 2.2 million in 2061" [33].

Biodiversity of the region is in decline [25], "biodiversity" here meaning the variety of indigenous (i.e., in situ) organisms ( $c f$. "native" species, but from other parts of Australia, and "exotic" 
species from outside Australia). "Exotic" species may be naturalised or nurtured; "indigenous" species may be extant or extinct.

Within the AMLR, there are now nine mammals and 17 birds, among other animals, that have become extinct, and 194 species of flora and fauna are listed as threatened (Table 1), the latter being especially prevalent in wetlands, heathy woodland and grassy woodlands [25]. Under Federal legislation, three ecosystems listed as "critically endangered" are the peppermint box (E. odorata) grassy woodland, the iron-grass (Lomandra effusa, L. multiflora ssp. dura) temperate grassland and swamps [25]. Among butterflies, Hesperia flavescens flavia is listed as "vulnerable", Jalmenus lithochroa as "Adelaide populations: municipal critically endangered" and Ogyris idmo halmaturia as "endangered" [34].

Table 1. A snapshot of the conservation status of species in the Adelaide-Mt Lofty Region [25].

\begin{tabular}{|c|c|c|c|c|c|}
\hline Group & $\begin{array}{c}\text { Total } \\
\text { Species }\end{array}$ & $\begin{array}{c}\text { Number } \\
\text { Extinct }\end{array}$ & $\begin{array}{c}\text { Number } \\
\text { Threatened }\end{array}$ & $\begin{array}{c}\text { Number Threatened } \\
\text { by Fire Management } \\
\text { Activities (Above } \\
\text { Threat-Level "Low") }\end{array}$ & $\begin{array}{c}\text { Number Threatened } \\
\text { by Inappropriate Fire } \\
\text { Regimes (Above } \\
\text { Threat-Level "Low") }\end{array}$ \\
\hline Flora & 1500 & 0 & 130 & 8 & 43 \\
\hline Fauna & 450 & 29 & $\begin{array}{c}64 \text { (plus } 9 \text { fish) } \\
\text { (Total: 194) }\end{array}$ & $\begin{array}{c}4 \\
\text { (Total: 12) }\end{array}$ & $\begin{array}{c}25 \text { (plus } 5 \text { fish) } \\
\text { (Total: } 68)\end{array}$ \\
\hline Mammals & & 9 & 2 & & \\
\hline Reptiles & & 3 & 11 & & \\
\hline Birds & & 17 & 50 & & \\
\hline Amphibians & & $\begin{array}{c}- \\
\text { (Total: 29) }\end{array}$ & $\begin{array}{c}1 \\
\text { (Total: 64) }\end{array}$ & & \\
\hline
\end{tabular}

Figure 5. Areas burned each fire season by (a) all fires and (b) prescribed fires only, from 1951-1952 to 2013-2014. Note the difference in the vertical scale.

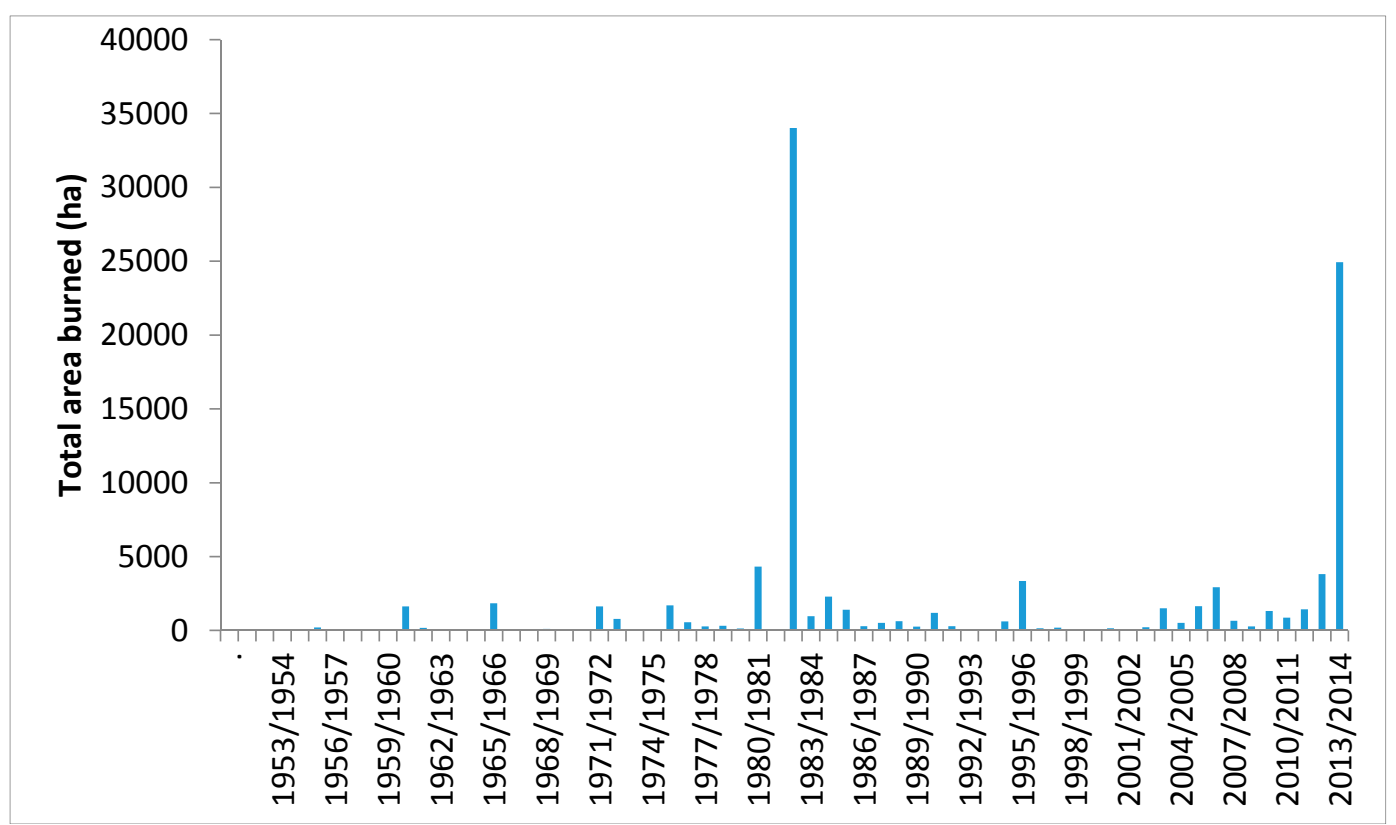

(a) 
Figure 5. Cont.

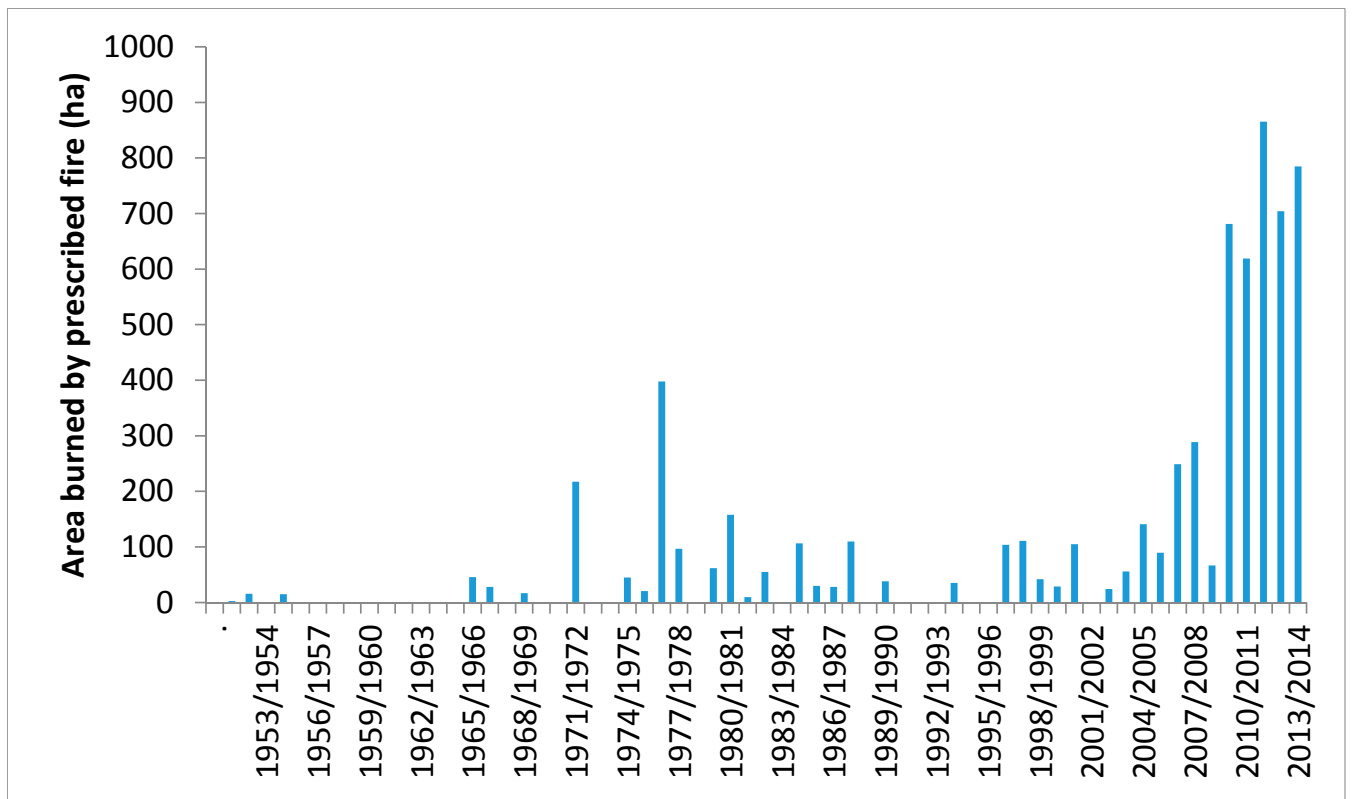

(b)

Unplanned fires ("wildfires" or "bushfires") have occurred throughout the history of the region from the early days of European settlement (Appendix). The mapped history of fires in the AMLR - both unplanned and prescribed - is patchy, but such records have greatly improved since the early 1970s. The total area burned per year is small in most cases, but two prominent spikes in the area burned by unplanned fires are in 1982/1983 and 2013/2014 (Figure 5a). In recent years, prescribed burning has become more of a feature (Figure 5b). Most fires occur along the spine of the region (Figure 1).

Willson and Bignall [25] recognised 68 species as being threatened by "inappropriate fire regimes", and a list of 12 species above a "low risk" and which are threatened by "fire management activities" (Table 1). They stress that fire issues interact with other issues and that knowledge is poor, so that accurate determinations of threat are difficult.

\section{Populous Adelaide, Fires and Biodiversity}

“...with man's progress (from settlement in 1836 to 1850), vast numbers of quail which used to frequent these parts have disappeared" ([27], p. 16).

In this section, the effect of high human populations on fires and biodiversity is outlined in the context of the European settlement of the Adelaide plains to become the Greater Adelaide area of today, stretching from Sellicks Beach in the south to the Gawler River in the north [35], a distance of approximately $90 \mathrm{~km}$. Fires may be largely eliminated from open places in the city and suburbs and biodiversity seemingly lost, so can cities and their peoples contribute to the conservation of a usually fire-prone biodiversity asset?

European settlers arriving on the Adelaide Plains in 1836 had an immediate need to establish a food supply. Part of this came from the land, part from the rivers: there were "plenty of kangaroos, wallabies, emus and opossums ... sometimes fish" [1]. Then, there was the need for the cultivation of 
gardens and crops and the pasturing of livestock: the easily cultivated grassy woodlands growing on the relatively rich alluvial soils would have been ideal [32], a legacy of Aboriginal land practices, such as frequent firing, as interpreted, controversially, from descriptions and paintings [37,38]. Firewood and structural timber for houses was also needed. These collective needs had an impact on biodiversity in the landscape from the beginning ([27], p. 16), and this would rise with the development of the city (Figure 4).

Today, in the Greater Adelaide area: "At least 132 native species of plants and animals have become locally extinct, and a minimum of 648 introduced species have arrived (mostly plants)" [35]. In the grassy woodlands and grasslands in the region generally, Paton et al. [39] highlight the decline of native species of birds, mammals and reptiles and the continued reduction and lack of tree regeneration. Extinctions have occurred, especially in mammals: Paton et al. [39] estimate the loss of 14 species in their "Mt Lofty Region", which is of a greater area than our AMLR.

The city (or town), along with its suburbs, experienced completely changed fire regimes and highly modified indigenous biodiversity. Numerous non-indigenous species of plants and large populations of introduced animals, especially birds, like pigeons, also became prevalent. In effect, a range of new, artificial, ecosystems has been constructed with often high inputs of energy in the form of digging, planting, potting, pruning, weeding, replacing and mowing of plants, along with inputs of water, fertilizer and sprays from external sources. The plant base of such ecosystems, in turn, has a variety of animals and invertebrates, fungi and microbes, etc., associated with them.

High-input ex situ actions for biodiversity conservation in a heavily populated area include conservation in zoos, botanical gardens, eco-gardens, public parks and private gardens. Nurserymen may need to simulate fire-stimulated germination of some species — after the manner of Davies et al. [40] for the flora of nearby Kangaroo Island to the south of our AMLR - in order to establish some plant species. Householders may grow native or introduced plants that intentionally or inadvertently support native animals and invertebrates. They might provide nesting boxes, water supplies and food for birds and other animals. Authorities may designate and manage certain areas as "biodiversity corridors", even in cities and suburbs. A part of Greater Adelaide, City of Salisbury, aims to "redress the loss of biodiversity in metropolitan Adelaide by ... increasing the bio-mass and corridors of locally indigenous species" [41]: this program may be seen as a subset of the regional program, Cape Border to Barossa Nature Link [42], the national program [43] and part of the international program [4].

In heavily populated areas like Adelaide, in situ conservation of remnants is challenging, but is seen as important in terms of providing heritage and amenity values and as a way of maintaining refugia for declining species. For example, the West-Terrace cemetery in the green belt of Adelaide (Figure 4) actively preserves remnants of native plant species typical of the Adelaide plains prior to European settlement [44]. The importance of this kind of conservation is highlighted by Shackley [45], who recorded the disappearance of 26 species in the Willaston cemetery, north of the city of Adelaide, in the last 50 years: this decline includes Choretrum glomeratum, the host for the butterfly, Ogyris otanes, a species with ant-tended larvae and considered to be "vulnerable" [34].

Perhaps in the few modified remnants of the area in which the restoration of the fire regimes presumed to operate at the time of settlement (but see [46] for edge effects prominent in small reserves), would this allow ecosystems to be self-sustaining? In Adelaide, "Up until about 1960, in those areas where animals were not grazing, the parklands were burnt annually rather than being 
mown" [47]. However, such practices will often be considered inappropriate in a city context, where smoke and flames may affect people's health and wellbeing, and high-value economic assets could be at risk. Close by are city fire stations, so there is high-level, rapid control of fire spread. Mechanical fuel treatments and inadvertent fire-mitigation treatment of fuel through irrigation and maintenance of lawns, gardens and road verges predominates. In 2003, 60\% of 509 plant taxa recorded in these parklands were introduced species [48].

Cities have potential for species' conservation that is intentional, active and persistent. The South Australian Government is a partner in the Urban Forest Biodiversity Program and the Urban Biodiversity Unit [49].

\section{Grassy Woodlands and Grasslands}

"The grass was very high. We had been for the last 3 miles going through what looked like high corn, but was really kangaroo grass, now seldom seen, and when the fire was lit to show us the way to the camp the grass took fire, burning miles of the country, fortunately to the north. Even now I can remember what a glorious sight it was." (16 February 1839) [50]

At the time of European settlement, woodlands virtually surrounded the spine of the AMLR formed by the Mt Lofty Ranges [39]. While Eucalyptus spp. seem to have been the most common dominants, Callitris (preissii) (e.g., north of Adelaide [50] and Allocasuarina verticillata, Banksia marginata and Melaleuca lanceolata [39]) was also prominent. Grassy woodland landscapes (and Australian landscapes at the time of settlement generally) are considered to have been shaped by Aboriginal burning practices, albeit controversially (e.g., see discussions in [37,51-55]): the same situation is found in North American grasslands [52]. Here, we examine woodlands of the AMLR and more widely, rather than just those listed as threatened in some way.

On the Adelaide Plains and in the Fleurieu Peninsula, only 4\% and 5\%, respectively, of the grasslands and grassy woodlands remain since 1836 [39]; "not a peculiarly Australian phenomenon" [56]. "Nearly $75 \%$ of declining native birds in south-eastern Australia are woodland birds", and Australian temperate lowland woodlands generally are "a disappearing landscape" [57]. These ecosystems are considered to be among the most threatened in Australia, a problem in common with North and South America and the chalk grasslands of Europe [56].

Today, the landscapes of the original grasslands and grassy woodlands of the AMLR are imprinted with the history of European agriculture through the presence of cropping and grazing systems, vineyards, orchards and plantations. Many pastoral lands are highly modified reflections of the structure and composition of the original vegetation due to: cutting, dieback or thinning of native trees; clearing of shrubs and grazing of tree regeneration in otherwise grassy understoreys; planting of windbreaks and shade trees; the presence of occasional fires, causing old tree collapse (Figure 6); fertilising; and cultivating for pastures and crops of introduced species. Needless to say, fire regimes have changed, but the ways in which they have changed in different areas is not known with any certainty. 
Figure 6. Grassy eucalypt woodland north-east of Adelaide in the Eden Valley fire area of January 2014. Note the apparent lack of tree regeneration across the pasture and the collapse of the tree on the left due to the fire (Photo: A. Malcolm Gill).

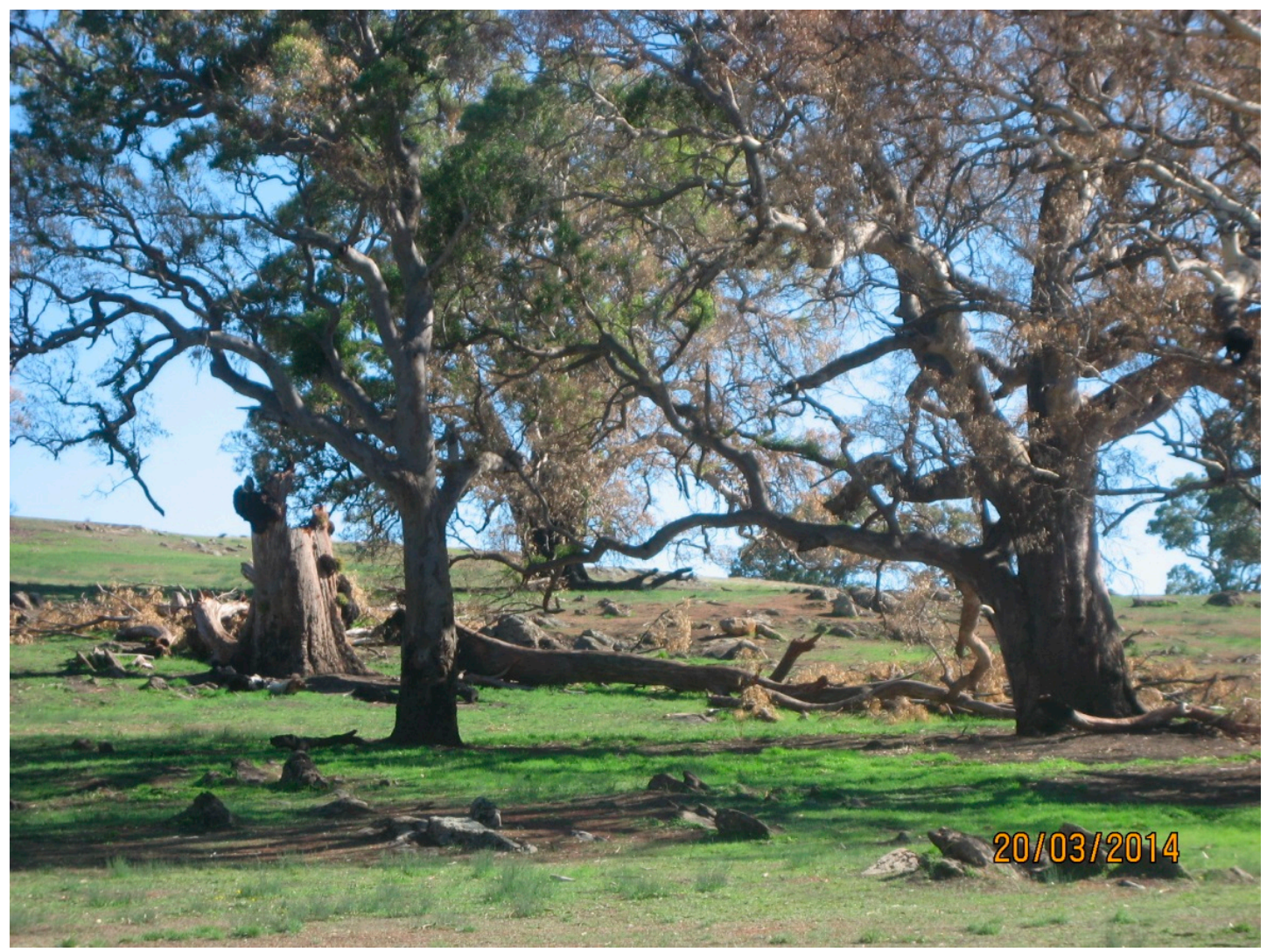

In highly fragmented temperate woodlands of Australia, such as those in the AMLR, most of the attention of zoologists has focussed on native bird species. Some bird species have become regionally extinct [58] while others are in decline [59]. The length of record of quantitative surveys may be too short to be definitive about trends, especially for the rarer species, but long-term negative outcomes may be lagged - the "extinction debt" [59]. Extinction might occur, for example, from extremes of "demographic stochasticity and environmental variation" (exacerbated by climate change [60]) or predation. Time lags are perhaps most obvious for the formation of habitat hollows following tree recruitment from natural or artificial means [61,62], although, presently, most declining species of birds in the AMLR are not hollow dependent [63].

Little attention seems to have been given in the literature to describing temperate grassy woodlands as ecosystems. An exception is Lindenmayer et al. [57], who highlight the interactions that can occur between tree condition, understorey composition, birds and leaf-eating insects; they point out that fallen logs and branches can be an important habitat for ground foraging birds, the echidna (Tachyglossus aculeatus), native mice and reptiles generally, while branches and tree trunks falling into streams have significance for biota there.

\subsection{Effects of Fire Regimes}

Lunt and Morgan's review [64] in Flammable Australia, the Fire Regimes and Biodiversity of a Continent [65] points out that there is a relative lack of fire research in Australian temperate 
grasslands. In a parallel chapter, but on temperate woodlands, Hobbs [66] also points out the paucity of research on his topic; he highlights the interactions between fire (interval, season and intensity), grazing and weed invasion. Most recently, Lunt et al. [67] consider from "limited data" that Australian grasslands and grassy woodlands ecosystems operate similarly to others around the world, with possible exceptions being the "relatively small influence of fires on grassland-woodland boundaries" and the persistence of a diverse flora under "very high fire frequencies".

In South Australian woodlands, Davies [68] concluded that short intervals between fires are likely to deplete populations of some obligate seed regenerators. His review pointed out that fires occurring in different seasons may have either positive or negative effects on both native and exotic plant species and that extensive high intensity fires can adversely affect populations of reptiles and mammals.

For temperate grassy woodlands in Australia generally, Fischer et al. [69] noted that: "the ongoing decline of tree cover deserves urgent attention ... (while) the tree regeneration crisis has received little attention in conservation policy". Observations of the senior author in woodland in the Australian Capital Territory suggest that: eucalypt regeneration in temperate woodlands is episodic and at various spatial scales; seedlings quickly develop resistance to low intensity fires; trees in general are very resistant to fire-caused death, but large trees are the most susceptible (Figure 6), either directly by fire or in the early years after post-fire resprouting; and, trees may flower on epicormic shoots within five years or so after defoliation by fire. In a drying climate, episodes of regeneration will become rarer, perhaps.

There are similarities between the demographics of temperate grassy-woodland trees and those in the tropics. Eucalypt species that dominate much of Australia's tropical woodlands resprout after fire and have rare recruitment events limited by rainfall [70]. Recruits can persist in the understorey for many years, being repeatedly limited in growth by oft-repeated fires [70]. In a tropical savannah in the Northern Territory, Australia, saplings, "juvenile trees", survived most fires, but wet-season fires killed nearly $10 \%$ of plants [71]; and stems of larger trees were the most susceptible to high intensity (late dry season) fires, while stem or plant survival in general was negatively related to fire intensity, but by no means complete [72]. The death rate of eucalypts of different sizes under different regimes over an extended period (say 500 years or more) is, of course, unknown, but may be pertinent.

Tree hollows are an important habitat for more than 300 species of Australian birds, mammals, amphibians and reptiles [73]. The trees containing most hollows may be perceived as distorted, dangerous to human well-being and unattractive due to the loss of large branches and tops. In the countryside, such remnant trees may be seen as sources of firewood, a source of embers when fire gains entry to tree "chimneys", making fire control more difficult, or as an inadequate shade tree for livestock. At the eastern edge of the city, there are hollow-bearing trees that may be a fire-risk factor. A minimum of 60-100 years may be required to develop hollows after planting trees in an Australian temperate zone [62].

\subsection{Livestock Grazing Regimes and Revegetation}

Paton et al. [39] reported the general opinion in South Australia that livestock grazing and introduced weeds and pastures limit the recruitment of trees, and in parts of the Mt Lofty Ranges, livestock ring-bark and kill mature trees. Recent research in areas of former temperate "grassy 
Eucalyptus woodlands and dry forest" in New South Wales indicated that particular grazing regimes affect the extent of eucalypt regeneration, viz. that rotational grazing with considerable rest periods was four times better than that with conventional grazing practices and the same as that without grazing [69]. Lunt [56] noted in his review that "deferred and rotational grazing ... may enhance the conservation of lowland grasslands and grassy woodlands in some cases", but "introduced stock ... will invariably diminish the conservation value of grassy ecosystems". He found that livestock grazing can prevent regeneration, and that the dominant food of the indigenous swamp wallabies (Wallabia bicolor) of eastern Australia can be eucalypt seedlings. These examples show that the species of animal and stocking rotations are important to the regeneration outcome. Indeed, the concept of the grazing regime, with the same components as the fire regime [5,6] - type (of animal), frequency of grazing, intensity of grazing and season of year [74] — is important to determine conservation outcomes.

Revegetation of woodlands is a recognised action for attempting to reverse trends in the decline of biodiversity in woodlands. However, Paton et al. [39] warn that inappropriate revegetation may be occurring through the use of shrub species that are known environmental weeds or species of inappropriate provenance. The extent to which revegetation is involved in the vegetation thickening and woody encroachment measured in Victorian grassy woodlands during the 16-year period to 2005 is unknown, but changes in land management and disturbance processes are likely causes, even though the causes are "challenging to untangle" [75]. Restoration programs may be initiated to try to recreate past ecosystems [1], but the success of the translocation of apparently suitable animals into "restored" habitat is not guaranteed [76]; the plant species used, or their provenances, can also raise concern [39].

\section{Forest Fires, Woody Weeds and Hills' Assets}

"As there was an abundance of stringybark, broom [woody weed] and blackberry (woody weed), the roar of the fire was terrifying" ([77], p. 6).

"The fire roared through the funnel formed by gullies, shooting out one end to incinerate forests, property, houses, stock and fences." [78]

Within the AMLR, fire behaviour may reach its fiercest in the wooded Adelaide Hills. Notable socially-disastrous fires have occurred there, especially in 1983 [79,80]. Such occurrences can dominate approaches to fire and indirectly affect fire regimes in public conservation reserves, as in neighbouring Victoria $[81,82]$. Affecting fire behaviour in conservation reserves and elsewhere in this region are fuels consisting of woody weeds (see the quotation above), "fuels" that, such as exotic weeds, are inimical to a biodiversity-conservation objective in an ideal system. In this section, fire behaviour phenomena are outlined, woody weeds exemplified and some of the social issues associated with fire noted. Later, below, in the section on species conservation using orchids and bandicoots as examples, the ambiguous role of woody weeds in supporting indigenous wildlife is mentioned.

The moister, higher "hills" near Adelaide provide some relief from summer heat on the plains, and in 1877, a Governor's summer mansion was built at Marble Hill with a commanding view of the region [83]. Many people other than Governor Jervois have had the same idea, but have settled full time in the forests there. Villages, small towns and isolated houses now dot the landscape: in the jurisdiction of the Adelaide Hills Council, there was a population in 2011 of 39,000 [84], while in the 
adjoining District Council of Mt Barker [85], there were 30,000 people. One of the attractions of living there, apart from cooler summers and a high quality village lifestyle, may be the presence of a discontinuous arc of conservation reserves approximately parallel to the perimeter of nearby Adelaide: a popular park, with 600,000 visitors per year, is Cleland Conservation Park [86]. However, the area is prone to bushfires and the economic and social damage they can cause: the former summer residence of the Governor is no exception, as it is now in ruins after burning down in the bushfire of 1955 [80] (Figure 7). For some people, at least in summer, the "fire or fear of fire is ever present and all-pervading" [87].

Figure 7. Ruins of the Governor's hilltop mansion, Marble Hill (inset). Cherryville is in the foreground. (Photos: David J. McKenna, May 2013)

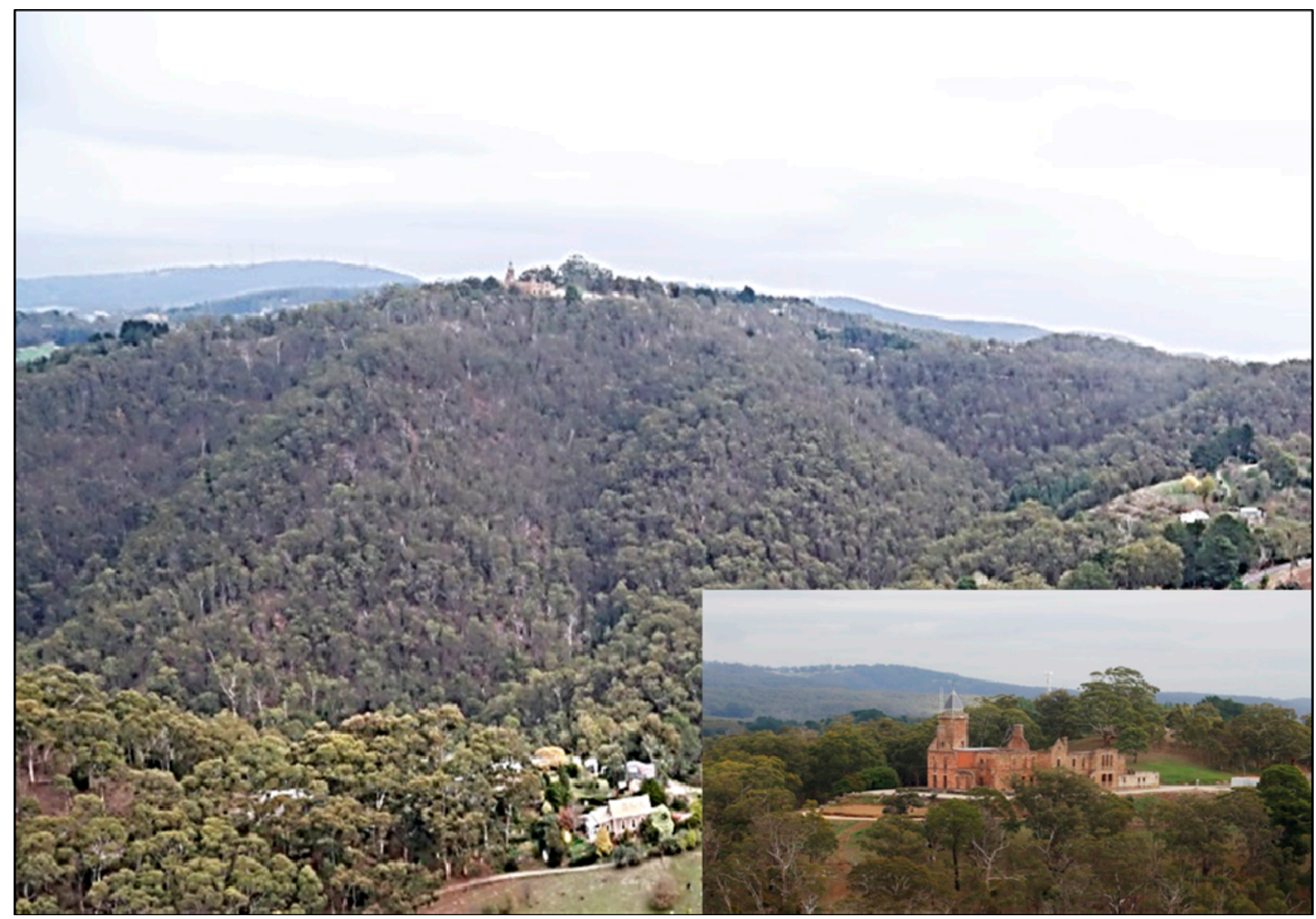

As the climate warms and dries, more people may seek cooler and moister climes in the higher elevation country of the region. Similarly, the biota of the warmer and drier parts of the region may spread into the higher elevation landscapes [22]. The biota of upper elevations may have distributions that shrink to "micro-refugia" as climate changes [22] and population density increases locally: what happens will also depend on new between-species competitive outcomes and new fire regimes.

The history of fires in the area is a long one. Buckman et al. [88] recorded fires in the upper Mt Lofty area back to 6000 years ago using stratigraphy and the dating of charcoal in peat and sediments. The latter part of this period had an average interval of 120 years $(n=10)$ between erosion-associated fires. On the basis of explorer Sturt's observations and the absence of 
archaeological records, Clarke et al. [87] concluded that: "the high altitude sections of the Mount Lofty Ranges, covered with closed-canopy stringybark forests, appear to have been largely avoided by all Aboriginal groups" (see also [89]). It seems likely that many other fires, not associated with sediment movement, also occurred during this period.

There has been a succession of seven fires recorded in the region in the 19th century reported from soon after settlement in 1837 (Appendix). There may be many more years of unrecorded fires, as a 19th century newspaper report in 1897 noted that: "as the first hot months of the year go by pillars of smoke rising here and there from the Mt Lofty Range become normal" [90]. In the 20th and 21st centuries, fires in the Adelaide Hills area have been recorded at an average interval of about two years (Appendix). Such lists should not be considered exhaustive, or uniform in terms of the area burnt, or in the same location on each occasion; they do not accurately reflect total areas burned, but emphasise the proneness of the area to fire.

Thirty percent of "vegetation fires" in South Australia occur in the Adelaide and Adelaide Hills area [12], viz. closest to the highest population density in the state. With time, more ignitions may be expected as the population grows, because in many parts of the world, the numbers of fires and population densities are related [15-19].

In Figure 1, the numbers of times areas have been burned in the period 1951/1952 to 2012/2013 is recorded. This map does not indicate the numbers of ignitions, which would be abundant, but it does provide an indication of fire interval, a variable of importance to biodiversity conservation [74]. The map includes areas burned as management interventions for the protection of social and economic assets. The areas burned by all fires and prescribed fires only are shown in Figure 5a,b, respectively. The prescribed fires mapped here are all on public land; the unplanned fires on public and private land. While a comprehensive analysis of all these data is beyond the scope of this paper, the data do indicate some of the geographic and temporal variability in the frequency of fires in the region; knowing and understanding the roles of all of the components of historical fire regimes, let alone their impacts on biodiversity, is extremely difficult.

With a regionally warming and drying environment [60], a statistically significant upward trend in fire-weather severity is being experienced in Adelaide [91]. The trend is likely to continue as predictions for days with higher levels of fire danger indices are expected to rise [92]. If fires have the opportunity to spread, therefore, intensities will be higher if fuel accumulation curves after previous fires remain the same.

Fuels may not stay the same, because with an increase in carbon dioxide in the atmosphere, an increase in plant productivity in the absence of weather changes may be expected [93]; deeper droughts could counter increases in productivity, such as that of grassy fuels [94]. In the drier parts of the AMLR, rainfall is likely to be limiting, while in the wetter parts, the situation is more equivocal. It is possible that in the Hills area, the effects of climate and atmospheric change on fuels and fires could be overcome by increases in fire-suppression capacity and management intensity in the form of programs of prescribed burning or mechanical fuel treatments. This depends, however, on the level of expenditure commitments of governments to extreme, but relatively rare, fire occurrences [95]. It may be impractical to immediately douse fires at their origin and prevent the spread of fire before it reaches intensities sufficient to cause significant damage to social and economic assets on all occasions. 
The conserved ruins of the Governor's summer mansion sited on the top of a hill with forested gullies leading up to it are symbolic of the economic and social assets at risk from bushfires in the area. In 1983, there were many fires in South Australia and Victoria on Ash Wednesday, 16 February. In the Adelaide Hills, 12 people died and 150 became homeless [80]. Such figures are only the headlines, however, as many other forms of economic and social loss are experienced, as well. For example, psychological disorders may develop [96]; and rural losses can be substantial, e.g., in the Tea Tree Gully/Anstey Hill/Gumeracha fire of 1983 [97]. In the AMLR, the wine industry is well known: the quality of wine grapes can be compromised by smoke, causing the wine made from them to be tainted to the extent that there can be losses of millions of dollars, as in the 2009 Victorian bushfires [98]. It is important to recognize losses and fear of losses of social and economic assets, as these affect managerial and policy responses to fires that, in turn, affect the conservation of fire-prone biodiversity.

Most fires spread in the steep topography found in the catchments to the west of the Mt Lofty Ranges divide. They spread under northerly, north-westerly to westerly winds initially, but can be markedly affected by wind changes, such as from the west and southwest in the 1983 episode [79]. Summer, nocturnal, downslope "gully winds" [99] can complicate firefighting [100-102], while sea breezes can also modify fire weather. The stringy-bark eucalypts (E. obliqua, E. baxteri) that are common dominants in the vegetation are an ideal source of burning brands for starting spot fires downwind.

Slopes in the area can reach 30 degrees [79], an angle that is in the critical range for the phenomenon known as "eruptive fire" $[103,104]$. This phenomenon may be the same as the "blow-up" on steep northern slopes in the Mt Lofty Region described by Cochrane et al. [100]. Lee-slope rotors (horizontal vortices) and fire channelling are also important phenomena associated with ridges aligned more or less perpendicular to the wind [105]. Such fire properties are critical, e.g., "Many fatal accidents are associated (with) sudden fire acceleration ... (on) steep slopes or canyons" [104]; fires can accelerate upslope in correspondence to energy growth in the fire over time without there being any change in external conditions [106]. "Flame attachment" [103] or "flow attachment" to slopes can occur, especially on steep slopes in enclosed gullies [106]: an image from the Cherryville fire in the Adelaide Hills in May, 2013, may illustrate this phenomenon [107].

Over 100 years ago, the local newspaper noted the effect of woody weeds on fire behaviour [77]; 50 years ago, Cochrane [108] also noted that they were a major fire-behaviour problem. Today, woody weeds in the area include Aleppo pine (Pinus halepensis), blackberry (Rubus spp.), boneseed (Chrysanthemoides monilifera), olives (Olea europaea), gorse (Ulex europaeus), broom (Cytisus spp. and Genista spp.) and Polygala spp. [109], plus Hawthorn (Crataegus monogyna) [110]. Woody weeds, and weeds 2-3 m tall, like African Daisy (Senecio pterophorus) in Belair National Park in the 1970s [111], can be significant fuel elements on abandoned farm land [100] and in native vegetation [108]. Cochrane et al. [100] found that two years after a fire, broom or gorse could form a "greater fire hazard" than mature indigenous vegetation, thereby having the potential to alter the between-fire interval and fire intensity.

Woody weeds, like olives, blackberry, hawthorn and broom, can form dense thickets on farms and in conservation reserves. Field observation of naturalised olives showed them to be often 3 to $4 \mathrm{~m}$ in height and of variable density. They were found in grassland and grassy woodland, often with only 
bare ground and litter beneath. Where dense, there was no understorey of vascular plants. It is difficult to quantify the role of "major fire hazard" that Cochrane [108] ascribed to them, but his observations seem reasonable for infestations of blackberry, olives and gorse under the most adverse fire-weather conditions, although retarding effects may be evident at low fire intensities; fire spread effects can arise according to the density of plants, associated vegetation, canopy height and age. It is stressed, however, that there has been no systematic, comprehensive study published on the topic.

Prescribed burning has been used extensively in Australia as a way of reducing fuels and potential fire intensity, thereby increasing the chance of fire control and the chance of protecting built assets, like the Governor's former mansion at Marble Hill (Figure 7). It has arisen from the practice of "burning off", which has now been formally constrained by guidelines and models and contextualised as "prescribed burning". Since settlement in South Australia, settlers, farmers and foresters have been the main users of fire. "In the period from 1980 to 2001, levels of prescribed burning conducted in South Australia (particularly in growing areas of urban expansion) were low" [109], but following the major 2003 bushfires in Canberra, Australian Capital Territory, prescribed burning in conservation reserves has become more prominent [112]; and following the benchmarking 2009 Victorian bushfires, "a prescribed burning program for 5\% (of) high risk public land each year" has been put forward as an official priority in South Australia [113]. Prescribed burning programs become part of the fire regime and, as such, also affect biodiversity [82] and, among other organisms, woody weeds.

Woody and other weeds are inimical to ideal conservation practice, so their removal or minimisation is a goal of biodiversity managers. If certain species exacerbate the rate of spread or intensity of fires, there is a more compelling case for their removal over and above that to be made for biodiversity conservation directly.

\section{Critically Endangered Swamp Vegetation: Land Use, Peat Fires and Biodiversity}

“... a week later, underground fires fed by 120 hectares of peat a metre deep, were still smouldering, sending up smoke visible for thirty kilometres" (in South-East South Australia) [114].

In this section, the "critically endangered" swamps complex classified under Australia's Environment Protection and Biodiversity Conservation Act 1999 [24,115,116] is examined. Those found on peaty substrates have a special significance here, because of the influence of people and climate change on their ignition, combustion, suppression and effects. With drying due to climate change, more frequent fire access to these sub-fossil substrates is likely, with potentially major changes to biodiversity. The roles of fires, climate change and agricultural practices on biodiversity are noted here.

"The flora that fringes and connects the ecosystems of the Fleurieu Peninsula Swamps Complex is diverse, with a large proportion of species being of regional, state and national conservation significance" [24]. About half of some 200 plant species are listed as being of concern under South Australian legislation, while the "Swamps Complex also contains significant regional, state and nationally threatened fauna", such as the "Mount Lofty Ranges southern emu-wren (Stipiturus malachurus intermedius) (and) the southern brown bandicoot (a small mammal) (Isoodon obesulus obesulus)". 
The vegetation of these swamp forms stands up to 3-m tall (Figure 8), some with stringy-barks- $E$. baxteri-on their margins. Peaty substrates in the AMLR are likely to support the shrub genera, Leptospermum and Viminaria, monocotyledons of the family Restionaceae and the genus, Baumea, and the fern, Gleichenia [117].

Figure 8. Swamp vegetation near Mt Compass, Fleurieu Peninsula. The bright green plant is the fern, Gleichenia (Photo: A. Malcolm Gill).

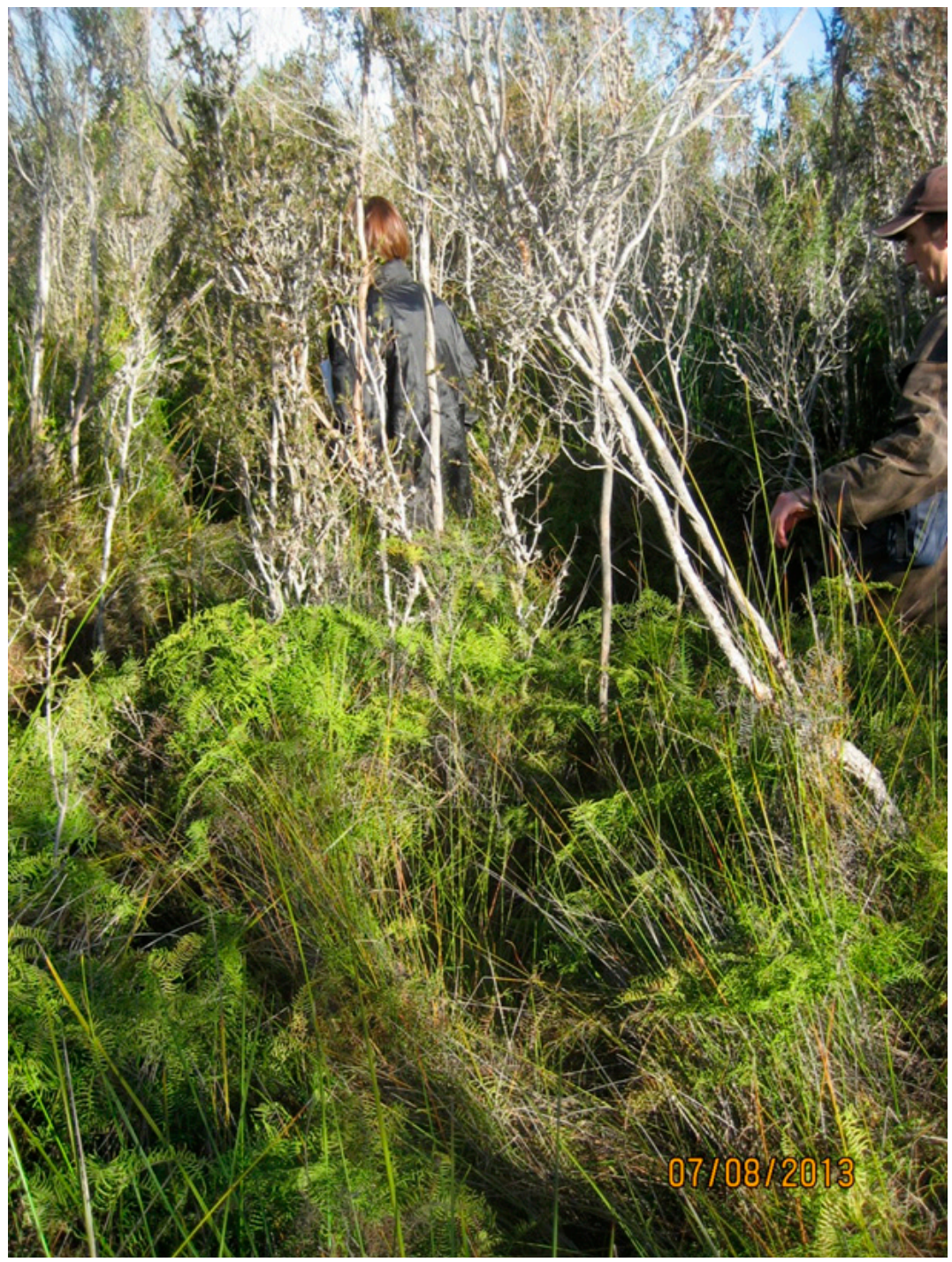

Peats are not widespread either in the AMLR or nationally, but, globally, peat deposits are considered to equal one third of the world's carbon-pool and to be about equal to that of all terrestrial sources [118]. Fires in peat are the slowest moving of all landscape fires, at up to about $12 \mathrm{~cm} / \mathrm{h}[119,120]$, but are difficult to extinguish [121] and likely to be the most costly to extinguish per unit area because of their persistence and the elaborate measures needed, such as moat (and mound) building [121] and flooding, as well as direct hosing [122].

Peats ignite under the wettest fuel conditions of any landscape fire - up to more than $110 \%$ on a dry weight basis in some cases [121] and in peats with mineral contents up to $80 \%$ [123] — and can burn for months [119]. They may have a slow spread rate, but can have numerous ignition points, due to the spread of the fire in the vegetation above; they can burn downwards, as well as laterally. In Australia, 
peat substrates may have accumulated over thousands of years, so fires burning down to mineral soil are necessarily extremely rare. Partial burning from above may be more frequent, and this is known to have occurred in the AMLR [117]. Peat fires generally could have been started by spontaneous combustion, but this can be difficult to prove [124].

Peat fires, arguably, perhaps, can have the most extreme effects of any fire event. Smoke from peat fires in Indonesia has shrouded landscapes and cities and neighbouring nations for months, thereby causing deaths and major adverse health effects with economic costs set at many millions of dollars [125,126]. Russia has had similar problems [127]; the 2010 heat wave providing a striking example [128]. Other effects of peat fires recorded in the international literature include the felling of trees and the removal of peat from agricultural fields in Canada [119] and "drastically" changing vegetation [123]. As a result of peat fires, soils may change their mineralogy, becoming more magnetic, as in the Everglades of Florida, USA [129].

To a large extent, the effects of peat fires in southern Australia are likely to mirror those of the national and international experience. Thus, even though Australian peat fires are small in area:

1. their smoke and ash is a health issue especially, perhaps, if it contains silica, a known carcinogen [130];

2. their smoke persists for extensive periods and causes local nuisance effects on road visibility.

3. they may cause the felling of stands of mature trees, as occurred in western Victoria in 2012 due to substrate combustion [131];

4. they may cause dramatic changes in plant-species assemblages, as in western Victoria, where the plant community became a "eucalypt monoculture with practically no understorey" [132];

5. they may cause changed hydrological conditions, such as in an area that burned for three months, "the ground sank, the creek bank collapsed, and large areas of burnt peat were washed away" [132]; and,

6. depletion of peat deposits represents a loss of "geohistorical and biotic information of the evolution of the wetlands" [130].

Peat-substrate fires in southern Australia have been ignited by prescribed fires as in southern Victoria, Australia, recently [133] and by unplanned fires, such as those in Victoria in [134]. Thus, the extents of peat loss from fires range from "no direct impact on the soil" to "soils burned to bedrock, losing thousands of years' worth of soil accumulation" [135].

Fire-control problems are likely to increase as more fires in peat may be expected to occur in the future. Thus, ignition is likely to increase as the exposure and drying of peat and other organic substrates becomes more common as a consequence of decreased water in swamps due to:

1. the predicted warming and drying of the climate in South Australia [60];

2. the increasing human population, which is likely to lead to an increase in ground-water extraction, due to the higher demand for drinking water and/or irrigating;

3. the growth of plantations, such as those with eucalypts or pines [136]; and,

4. an increasing intensity of land use, including the draining of wetlands. 
While peat fires and their extreme effects have been the focus of the discussion above, fires are more common in the vegetation above than in the peaty substrate. Fire behaviour there is largely unknown. Stands of Typha, a food source for Aboriginal people, with a similar phenology and form to Phragmites stands found in the AMLR, are green during spring and summer, but start to cure in autumn and have dried-out stalks over winter; stands were probably burned in autumn and early winter in pre-historical times [137]. Gleichenia, a bushy fern that retains dead fronds and often found with Leptospermum, is another major fuel element: it carries dead material throughout the year and is likely to be a prominent fuel in summer fires. Swamp vegetation can carry fire, even when there is surface water present.

In the peat swamps of south-western Western Australia (WA), the sunset frog, Spicospina flammocaerulea, may be vulnerable to "inappropriate fire regimes" [138], but for the swamps in the AMLR, the Australian Government [24] does not list "inappropriate fire regimes" as a threatening process. However, a bird species - the Mount Lofty Ranges southern emu-wren (Stipiturus malachurus intermedius) — is listed, and fires, not necessarily peat fires, seem likely to be involved in its persistence $[87,139,140]$. This bird species went locally extinct after the Ash Wednesday fires of 1983, but the effect was offset by subsequent translocation [141].

The effects of fire regimes on the many species of concern in the wetlands of South Australia need to be investigated. Early indications are that major successional changes in dominants or subdominants can occur after fire [117], but little appears to be known of the fire-regime responses of the 200 plant species and several animal species [24].

\section{Species Conservation and Fires: Orchids and Bandicoots}

"The major threats to the Southern Brown Bandicoot (eastern) [include] inappropriate fire regimes and extensive wildfires ..." [142].

Species in decline or in small remnant populations are often the focus of attention for authorities concerned with their conservation. An ongoing challenge in fire-prone environments globally is to define or understand appropriate fire regimes for the management of these species. Much of the threshold-based fire regimes implemented in Australia and elsewhere are derived from an understanding of plant persistence strategies and times to maturity. There is a great deal more uncertainty around time to senescence, as well as the impacts of changing fire season, varying fire intensity and fire frequency [143]. Understanding spatial aspects of these fire regime elements at a landscape-scale is also challenging. In this section, we provide examples that highlight some of the challenges involved in understanding fire regimes and management for flora and fauna. We have chosen orchids to highlight the importance of season of fire as a significant variable for conservation and a bandicoot-a small ground-dwelling marsupial - to highlight the importance of fire interval and patchiness. The examples help to illustrate the scientific and practical issues associated with effective monitoring and applied research. Interactions, such as those between feral predators, fires and their management, are noted.

In the list of threatened vascular plant taxa in the recovery plan for the AMLR [25], orchids are prominent in having 47 taxa listed from the total list of 128 angiosperms and ferns, being approximately 
one third of entries; here, we examine a selection of four of those for which fire responses are mentioned in the literature. We also examine the case of a "vulnerable" bandicoot, one of two mammals on the 164 terrestrial vertebrate list [25], in relation to fire events and fire regimes, particularly in shrubby communities or shrubby understories of the AMLR.

Among the orchids listed by Willson and Bignall [25], 38 are classed as "endangered" in the region and nine as "vulnerable". For the 36 taxa given a "broad vegetation preference" among the six categories for orchids, 14 were in heathy communities - either "heathy woodland" (twelve) or "heathy forest" (two) - and seven are in the "grassy woodland" category: thus, 39\% are found in heathy communities. Heathy woodlands and forests are mostly dominated by species of Eucalyptus and have an understorey of sclerophyllous shrubs.

Duncan [144] defined five categories of orchid response to the benchmarking 2009 Victorian bushfires. His classification was based on population survival (killed or damaged) and, for undamaged populations - implied - flowering behaviour (neutral, stimulated or dependent). He noted that even in terrestrial species, populations may be killed due to the exposure of bulbs and the intensity of fire; if bulbs were killed, replenishment of the population must come from seed dispersed into the area. This highlights the importance of flowering and seed setting; however, grazing by native and introduced herbivores can have marked effects on the flowering of some orchid species [144]. Inappropriate fire regimes interact with other threats, so that their role in affecting species persistence is difficult to determine [25].

Damage, or "inhibition", by fire seems to be a feature of autumn and winter flowering species ([145], from [144]), which often have shallow tubers [146]. Many of the winter flowering orchids are also clonal and can therefore take much longer to recover and colonise burnt areas [146]. In the present study area and surrounding region, Quarmby [147] noted that several threatened Caladenia species (spider orchids) were known to survive summer fires, a time coincident with their dormant phase; as a corollary, they are most vulnerable to fire when they are actively growing, especially in autumn and winter, when the tubers are being replaced and mycorrhizal associations are being re-established [147]. For some species at least, bulbs can remain dormant for periods of one to three years [148], so not appearing annually in population monitoring programs [149].

Four of the "endangered" orchids of the AMLR are singled out for special mention. The first is the Kangaroo Island spider orchid (Caladenia ovata), a species that is said to seldom flower, except after bushfires, and that is threatened by inappropriate fire regimes [150]. The recent information is that the species can flower in some places without fire, yet, elsewhere, fire may lead to its invigoration and flowering as a response to the removal of cover [146]. The second species, the short-leaf donkey orchid (Diuris brevifolia), "Grows among shrubs in dense stunted forest and low heath in moist to wet soils; sometimes on swamp margins" and is threatened by "lack of fire" [151], but like the previous species, its responses may be explained by the removal of cover [146]. The third species, the blue top sun orchid (Thelymitra cyanapicata), occurs in swampy woodland with a dense understorey, flowers more profusely after fire and could be affected by dense cover [152] and, therefore, fire regimes. For the fourth species, the Hindmarsh Valley greenhood orchid (Pterostylis bryophila), an indirect effect of fire arose when an intense fire led to a very dense regeneration of, and competition from, a native shrub, Acacia paradoxa, and a weed, Senecio pterophorus, thereby reducing populations [153]. While there is a direct or indirect fire connection with each of these species, more information is needed. 
Among the animals that inhabit dense woody vegetation types in the region (Figure 9) is the southern brown bandicoot (Isoodon obesulus obesulus), a small mammal that occurs across southern Australia in habitats that are largely fragmented [154]. It is officially "endangered" nationally and "vulnerable" in South Australia [142].

Figure 9. Southern brown bandicoot habitat. Cox Scrub Conservation Reserve, Fleurieu Peninsula (Photo: A. Malcolm Gill).

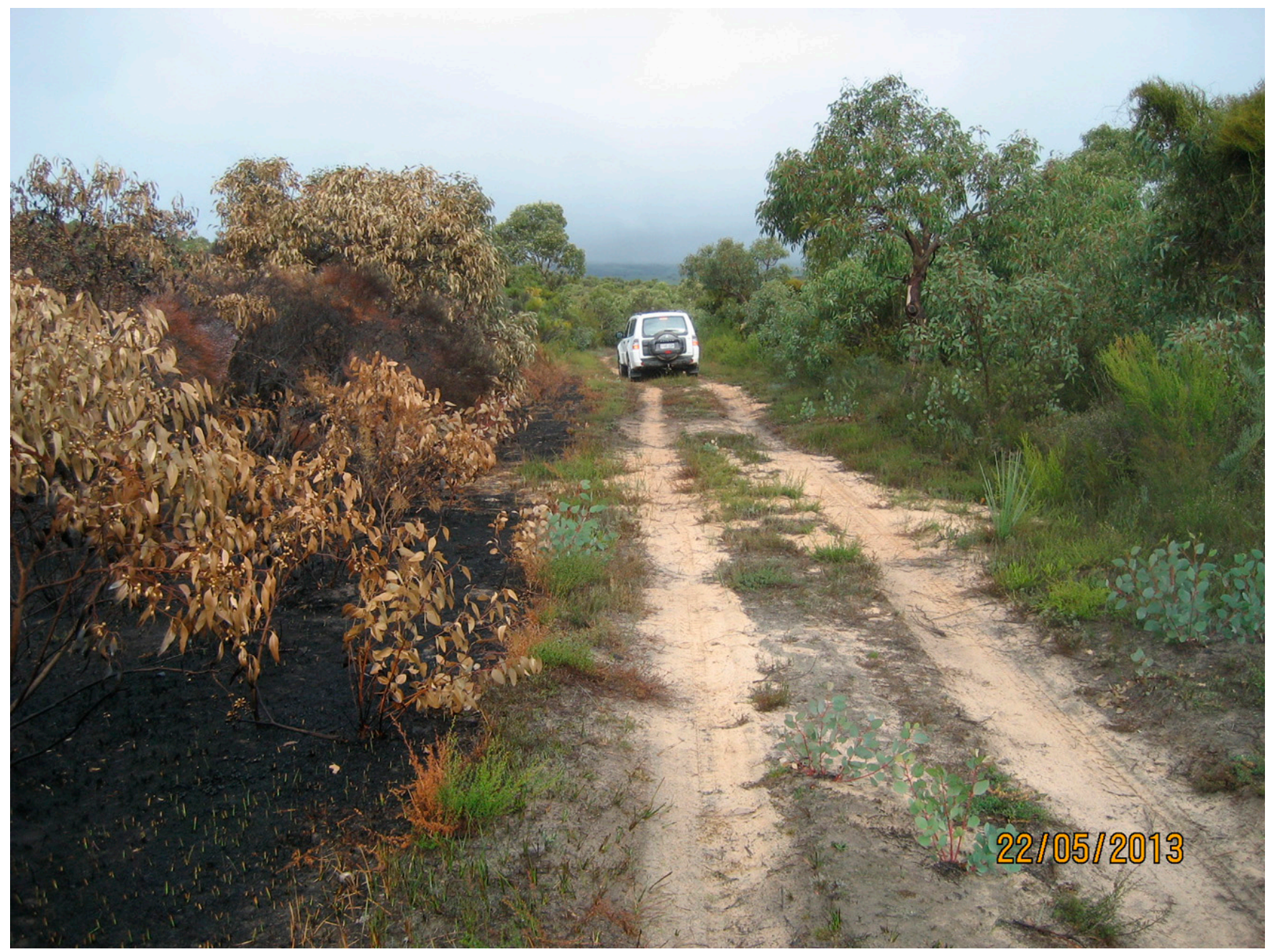

Evidence is mounting that the bandicoot of interest here digs burrows that might provide it with shelter in bad weather and during prescribed fires [155]. Thompson et al. [156], among other investigators [155,157], found that bandicoots survived a prescribed burn, but the number of animals observed was small in all three studies. Hope [157] noted that bandicoots may not even survive low intensity fires at times. In an area of the northern Fleurieu Peninsula, Thompson et al. [156] found no bandicoot sign, or the animals themselves, after the high intensity Ash Wednesday bushfires of 1983, and they did not reappear during the first ten years after the bushfire "despite extensive efforts" to detect them; and they had not reappeared in this area up until the time of Gepp's 2005 report [158].

The absence of these animals after the Ash Wednesday fire could have been due to:

1. the killing of the population by high intensity fire; 
2. the depredations of feral predators [157], like the introduced European fox (Vulpes vulpes) or feral cat (Felis catus) [159] soon after fire; or,

3. the lack of unburnt habitat in the immediate area in which a remnant population could have persisted and recolonised the area [155].

The importance of there being a remnant population in a reserve was highlighted by the aftermath of an unplanned fire in 2000, which burnt $96 \%$ of the 450 -ha Wandilo Native Forest Reserve in south-east South Australia in which bandicoots persisted in a remnant of unburnt bushland [158].

"Although it appears that the species may be favoured by the careful and strategic use of prescribed fire, more information is required on the scale, intensity and timing of burning for conservation of the subspecies" [142]. The significance of scale in bandicoot conservation in south-eastern South Australia was noted by Possingham and Gepp [160] through their recommendation that at least three prescribed burning "management units" would be part of their optimal strategy given the limited information available to them. Such advice on the "timing" (assumed to mean "season") of prescribed burning for the bandicoot, but perhaps "interval", should be considered in light of the behaviour of orchids, certain species of which are detrimentally affected by burning outside of their dormancy period (see above).

Issues of scale [142] include the demography of fire patches with vastly different areas [161]. Patchiness of some form or another in fires is unavoidable and may or may not be random. Just how these patches change with time [161] is not often considered. Mosaics of patches may be created naturally within a fire event [161]; or may be seen as consisting of a variety of times since fire or patches with different histories and, as such, recommended for a single species, like the southern brown bandicoot $[162,163]$. Details of the shapes, sizes and dispersion of the patches in the mosaic are usually lacking. This is not surprising, because it is no simple matter to ascertain what is best for a single species, let alone the biodiversity of an entire ecosystem; "Which mosaic?" is appropriate [164]. That the southern brown bandicoot occurs on Kangaroo Island [142], neighbouring the AMLR, and persisted there without the influence of Aboriginal firing practices for thousands of years [165] suggests that assumptions about the nature and role of mosaics created by such practices are at least questionable in this case.

A review of threats to the southern brown bandicoot across south-eastern Australia [142] noted five main classes of problem, which are summarised here as: introduced predators; habitat change; fragmentation; inappropriate fire regimes; and isolation of populations. Habitat change through clearing "for urban, agricultural and pastoral use has been implicated in the local extinction of populations" of the species; weeds, stock grazing and Phytophthora root disease (introduced) have all been implicated in adverse habitat change, as well. The evidence for the importance of fire regimes presented in the review is mixed, but this could be because of different predator profiles, understorey densities and fire regimes. Aitken [166] attributed the decline of the bandicoot in south-east South Australia, in part, to too-frequent burning, which thins the vegetation and, in turn, assists predation by foxes. This is symptomatic of the problems with managing fire regimes for the conservation of many fauna; a comprehensive understanding of fire-regime responses is lacking relative to what is known about plants. Until greater consideration is given understanding links between fauna and fire regimes, plant-derived thresholds will be used as surrogates, but often with unknown consequences [74,167]. 


\section{Discussion}

"The settled areas of South Australia are within a natural environment which is bushfire-prone. This is a basic truth around which all else must revolve." [168].

"No Species Loss" policy: “... the aim is to lose no more species in South Australia ..." [169].

"Nature today is more about cities and farms than wilderness." ([170], p. 47).

The AMLR is part of a national biodiversity "hotspot" [21] embraced by the State-wide policy of "no species' loss" [169]. Providing an administrative framework for the "no species' loss" policy are the South Australian Government's Department of Environment, Water and Natural Resources, the Natural Resources Management Boards, the Biological Survey of South Australia, and the Urban Forest Biodiversity Program and its Urban Biodiversity Unit. The Conservation Council of South Australia and other grassroots organisations and individuals lend support to conservation efforts. Local government has inputs through its development of connectivity links, such as in the Town of Gawler [171], where "minimising species loss" through the creation of biodiversity corridors, among other measures, is an objective. Despite this, the biodiversity resource is considered to be declining because:

1. many species have become extinct at local, state and national levels;

2. many species are formally listed as threatened, endangered or vulnerable at state or national levels; and, similarly,

3. a number of vegetation communities and their dependent fauna are under threat.

A broad generalisation to explain the decline of biodiversity is that it is due to the fragmentation of ecosystems (and attendant effects). This suggests that expanding the public conservation system, through the purchasing of land for connectivity corridors and creating new reserves, could assist in solving the problem. Indeed, it may do so to a lesser or greater extent, but the effects of fragmentation include the effects of changed processes within and outside reserves and fluxes of species across boundaries, all of which could vary from place to place. There is no single, practical, clear-cut answer as to why so many species are under threat: there are multiple possibilities.

Trying to isolate specific causes of biodiversity decline for a single species may be very challenging because of its small populations, sometimes found in disparate localities. Within a category of causes, such as "inappropriate fire regimes", identifying the specifics for a species, such as the regimes that are appropriate and those that are not, is difficult. Responses to aspects of fire-regimes include the apparent importance of fire intensity (e.g., on Stipiturus malachurus intermedius [141]), the seasonality of fire (orchid examples), peat fires (see the peat fire section above) and fire interval (see the section on Bandicoots). There are likely to be interactions between the effects of these variables, all components of the fire regime [5,6]. We know very little about the responses to fire regimes of many of the thousands of vascular plant species of terrestrial Australia, let alone all of the micro-organisms, fungi, cryptogams, invertebrates and vertebrates indigenous to the continent, for example. The same is true world-wide. 
Not all species in situ are to be found in public conservation reserves, the places of seemingly highest administrative security. Indeed: "It is likely that not just the reserves but the entire remnant ecological system in the agricultural regions of South Australia is not representative of the regional environmental variation" [30]. Some populations of species, like the "vulnerable" southern brown bandicoot [25], are found both in and beyond the boundary of Belair National Park, for example [110]. Outside of reserves, especially, the negative impact of human population density on biodiversity is everywhere to be seen, especially in cities. Even within the conservation-reserve system, certain fire regimes and management activities aimed at constraining fire spread may have adverse effects on some components of biodiversity [74]. Smoke, spreading beyond reserve boundaries, may have adverse effects on vineyards and human health [20] and provoke public reaction to fires in reserves. Smoke can also have a major influence on the germination of some Australian species, e.g., [40], but also species in Africa and the USA [172] at least.

Bushfires and the biota spread wherever they can. They are not constrained by jurisdiction. The biota responds to habitat-atmospheric composition, weather and climate, soil type and depth, vegetation structure, species' composition and disturbance regimes, including fire regimes. Bushfires, in a sense, also respond to their habitat: weather (temperature, relative humidity and wind), soil type (organic or inorganic), ignition environment and vegetation structure, composition and fuel properties at various scales (e.g., for the latter, see [173]) and topography. Neither bushfires nor elements of the biota are concerned with distinctions between "native", "indigenous" or exotic, feral versus tame, town versus country; indeed, the indigenous biota, like the southern brown bandicoot, in the AMLR may feed on the fruit of woody weeds [159] and shelter under blackberry thickets [174], while fires, in the wider sphere, can be more intense in some pastures or crops of exotic species than in those of native species on the basis of their biomass when cured (e.g., in introduced Gamba grass, Andropogon gayensis, in northern Australia [175]) or less ignitable in others, such as in irrigated crops.

The examples of species' status and the effects of fires raised in the sections above cover a spectrum of situations from city to rural, from artificial to "natural". "Indigenous species" may be found in public and private conservation reserves, but also on public and private property with prime objectives of management other than biodiversity conservation (e.g., see [170] for Australian examples). Thus, for the comprehensive application of the "no species loss" policy, a whole-of-community involvement (see above) may be envisaged, as apparently intended by the departmental policy in South Australia [169] and administrative structure. Similarly, fire matters need to be high in the consciousness of all inhabitants of, and visitors to, the fire-prone landscapes of the AMLR. Fires are already an issue of public safety; fire weather is becoming more severe [91]; and fire regimes for biodiversity conservation are likely to become even more difficult to design, implement and control.

Whole-of-community "projects" are difficult to implement, because not everyone is likely to agree with their objectives. Even if they did agree with them in principle, people often have higher priorities for their use of time and money. Even government implementation of best practice may be compromised among different arms of government by different perceptions of community priorities, allocations of funding, rules of engagement with different jurisdictions and powers and motivations. Dilemmas regarding value, or appropriateness, arise in the field: koalas (Phascolarctos cinereus) are probably an introduced species in the Mt Lofty Ranges [176], with individuals readily exposed to fires, but an icon 
and tourist drawcard; naturalised shrubs and trees - woody weeds - are out of place in conservation reserves, yet may provide food for indigenous species of birds or shelter for small indigenous mammals [159].

Both bushfires and the biota can have negative or positive effects on social, economic and environmental assets. Fires can destroy houses and lives; feral animals can destroy wildlife and livestock. Fires can benefit biodiversity if within the bounds of the appropriate fire regime; prescribed fire programs can keep fuels at lower levels than they otherwise would be, thereby helping to mitigate fire intensities and, thus, reduce the potential impact of unplanned fires on various assets nearby. "(C)hanges in fire management" may be a "major threatening process" for many of Australia's bird taxa [58], but can also be seen as a necessity within the emergency, land use and financial context in which such operations occur.

Concerns about both unplanned fires and biodiversity are being addressed at local through to international levels in Australia. For unplanned fires, there are international agreements for the exchange of fire fighters and equipment, while for biodiversity, there are a range of agreements, such as those relating to migrating birds, for example [177]. In the AMLR, fire suppression operations are integrated across metropolitan and country fire services. Other aspects of fire issues, such as planning controls, community engagement, fuel management and ignition control (especially arson), seem more disparate, less prominent. Fire management actions affect all land uses, whether this is through the construction of fuel breaks, the use of water in dams, the use of additives in water for suppression, the cutting of fences, prescribed burning programs, grazing regimes, etc. [74].

Rural lands, whether as farms, rural-residential blocks, indigenous forests or plantations, water-supply reserves or road verges, can have a role to play in biodiversity conservation and unwanted-fire mitigation. This is being done to a limited extent already. In agriculture, there is the potential for enhancing the roles of indigenous and native species as part of cropping, shelter-belt and grazing systems. On rural-residential blocks, niche cropping of native species as food supplements could be further encouraged. In forestry areas and water supply reserves, there is potential for in situ conservation and enhancing conservation value through replanting with indigenous species. While there are a range of options, including being part of connectivity areas for biodiversity conservation, there are fire implications and adjacent land uses to consider.

The AMLR exhibits in microcosm many of the challenges faced by conservation managers in the wider fire-prone world-increasing human populations, changing atmospheric composition, changing climate, changing fire regimes, changing land uses and increasing land use intensity-resulting in the loss of biodiversity and increasing numbers of naturalised species. The extreme case of changed ecosystems is already with us (in the city and its suburbs), where ecosystems are based on plants introduced into gardens, as well as naturalised plants and indigenous species; where fertilisers, herbicides and pesticides are common; where mowing, watering and planting are routine; where temperatures are higher than the surroundings, because of the urban heat island effect; and where a range of new microclimates associated with buildings abound. Animal populations in these ecosystems may be artificially fed and watered, confined to various degrees, have new habitats in the form of ponds and buildings and face large feral populations of introduced predators, like foxes and cats. At the other extreme to such urban areas are relatively pristine areas, while in-between are peri-urban, rural, forestry and protected catchment areas. 
Our society faces major practical and conceptual issues related to our changing fire regimes and declining biodiversity. There is a need to address decline in biodiversity by seeking and achieving:

1. effective and demonstrable connectivity through bio-links between all public reserves and all private remnant sites;

2. strategic habitat restoration;

3. enhanced conservation management across tenures;

4. promotion of the "big picture" concepts, like all-tenure, whole-of-landscape [23] and whole-of-community approaches; and,

5. fire regime management in all conservation management planning and actions'.

There is also a need to:

1. anticipate the nature of more densely populated landscapes under climate change, land use change, soil change (e.g., peaty substrates) and new aggregations of indigenous and introduced species forming an increased range of "novel ecosystems" [178], a "new nature" [170], managed with a range of synthetic fire regimes [82];

2. address species-based conservation in private urban, peri-urban and rural areas generally, with a view toward the continuity of conservation achievement through time, despite changes of land ownership;

3. determine the responses of indigenous species to fire regimes [143], including responses to variation in fire interval and intensities and times of year (and peat fires where relevant);

4. understand and respond to lags in tree-population change (and fire regimes) and its consequences for the habitat - the "extinction debt" [59] and barriers to species migration that could cause species' population decline;

5. measure and record the status of biodiversity across landscapes from cities and towns to far-flung areas and respond adaptively and comprehensively; and,

6. record the occurrence of fires across the entire landscape more comprehensively, including the locations of fires in crop residues and the passage of unplanned fires across private land, along with the locations of all ignition points.

There are a large number of possibilities for bettering the chances of successful biodiversity conservation. The underlying challenge is to maximise the number of people that are aware and concerned about fire and biodiversity issues, either as separate issues or joint. For fire matters, addressing the issues of unwanted ignitions, fire suppression and fuel management within the context of the social, environmental and economic assets of concern, not just operations, is essential [20]. While ecologists have learned a great deal about biodiversity and the environments that sustain them, this knowledge is far from complete, and the continuing change in our landscapes, climate and atmosphere amplify the need for practical systems of biodiversity assessment and adaptive management if society is to realise its goal of no species loss in a changing fire-prone environment.

Effective management of the fire-prone biodiversity of the region is limited by a set of issues that are mirrored in other fire-prone environments globally. These include a lack of knowledge of the status and workings of present-day modified ecosystems, let alone new ones, knowledge of the effects of fire 
and grazing regimes across landscapes generally, the connectivity of reserve systems, adequate resources for management (including whole-of-landscape fire and fuel management, adequate monitoring) and appreciation of the biodiversity asset by land users with a range of value systems.

There is no simple, quick, unilateral and inexpensive action that will resolve all of the issues associated with fire regimes and biodiversity conservation in the AMLR; that is why a co-ordinated, collaborative approach that uses targeted and effective programs dictated by local and regional land use legacies, and changing geographical and social contexts, is necessary.

\section{Conclusions}

Fire-regime management and conservation of biodiversity are important priorities in the AMLR. Biodiversity is in decline, and fire intervention in management is increasing. A wide range of circumstances and species' responses are found. Fires and species travel where they can, but their spread is restricted by fragmentation, land use and other forms of human intervention. With changing populations, climates and atmospheres, fire occurrences and locations of suitable habitats for the biota are likely to change. Being prepared as much as possible for these changes and adopting a pro-active all-tenure, whole-of-landscape and whole-of-community approaches to conservation and fire management seems reasonable. It appears that in the AMLR, these integrating concepts could be promoted more widely and vigorously using the administrative structures and policies that are already in place.

\section{Acknowledgments}

We would like to thank: Leigh Miller, Donna Bagshaw and Pip McGowan (South Australian Country Fire Service); Rebecca Duffield and Tim Vale (Conservation Council of South Australia); Adrian Shackley of the Gawler Environment and Heritage Association; the staff of the South Australian Department of Environment, Water and Natural Resources in Adelaide, especially Kirstin Abley, Joe Quarmby, Randall Johnson, Anne McLean, Felicity Smith (Biological Survey of South Australia), Simeon Telfer and Alex Otterbach, Simon Wicks and David Taylor; and Barbara St John of Natural Resource Management South Australia. Special thanks are given to Rebecca Duffield, Joe Quarmby and David Taylor, who expertly commented on selected sections of the draft manuscript, and Kirstin Abley and Randall Johnston, who did so for entire drafts.

\section{Author Contributions}

All authors were involved in the project from its outset and all were involved in the preparation of the manuscript.

\section{Conflicts of Interest}

The authors declare no conflict of interest. 


\section{Appendix}

Table A1. Reports of bushfire years in the hills and ranges of the study area since European settlement in 1836. The data sources in the Table are largely from newspapers and are the result of personal searches and the sharing of materials with Ms. D. Bagshaw. "Extents" are not necessarily annual totals nor the total for any group of fires noted.

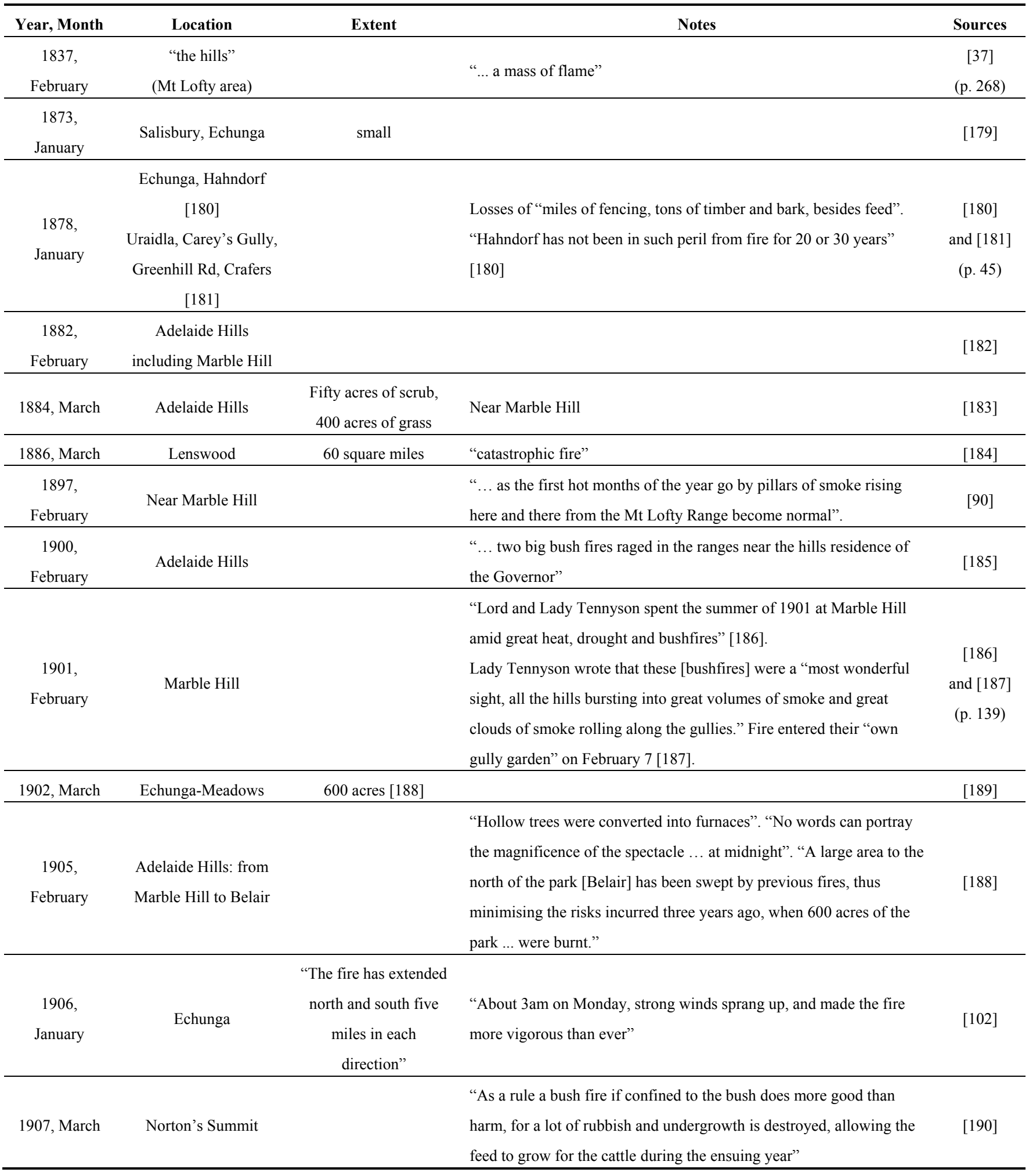


Table A1. Cont.

\begin{tabular}{|c|c|c|c|c|}
\hline Year, Month & Location & Extent & Notes & Sources \\
\hline 1909, February & Near Cherryville & & $\begin{array}{l}\text { "... regarded as the worst experienced in the } \\
\text { neighbourhood for four years" }\end{array}$ & {$[191]$} \\
\hline 1910, February & Marble Hill & & $\begin{array}{l}\text { "... settlers ... beat down the flames" "A fire } \\
\text { swept up the valley towards (Norton Summit). } \\
\text { Marble Hill: "The flames surged from hilltop } \\
\text { to hilltop". "The flames swept up a gully to the } \\
\text { side of the Bungalow (at Marble Hill)" }\end{array}$ & [192] \\
\hline 1912, January & Marble Hill & & $\begin{array}{l}\text { "... vice-regal residence at Marble Hill } \\
\text { narrowly escaped destruction"; "the } \\
\text { stringybark and thick undergrowth provided } \\
\text { excellent fuel"; ".. happily the conflagration } \\
\text { had confined itself to the scrub"; "strong wind } \\
\text { from the west" "pace estimated at fully } 10 \\
\text { miles an hour" "sparks falling from the burning } \\
\text { trees on to the roofs" }\end{array}$ & {$[193]$} \\
\hline 1912, February & Adelaide Hills & & $\begin{array}{l}\text { "... most appalling blaze that has ever been } \\
\text { experienced in this portion of the State" [194]. } \\
\text { "This was without a doubt a Black Thursday } \\
\text { for Hahndorf and never before was } \\
\text { such a terrible scene witnessed" } \\
\text { (A map of the fires is presented.) [195] }\end{array}$ & {$[194,195]$} \\
\hline 1914, January & Adelaide Hills & & $\begin{array}{l}\text { "An extensive bush fire in the hills was visible } \\
\text { from the city." }\end{array}$ & {$[196]$} \\
\hline 1916, March & Adelaide Hills & $\begin{array}{c}\text { "It (the fire) } \\
\text { assumed serious } \\
\text { dimensions" }\end{array}$ & & [197] \\
\hline 1918, February & Montacute & $\begin{array}{l}\text { “... extended over } \\
\text { a distance of from } \\
10 \text { to } 15 \text { miles.” }\end{array}$ & $\begin{array}{l}\text { "A devastating bush fire swept the } \\
\text { Adelaide Hills" }\end{array}$ & {$[198]$} \\
\hline 1920, February & Adelaide Hills & $\begin{array}{l}\text { “. large area of } \\
\text { scrub" [199] }\end{array}$ & $\begin{array}{l}\text { “... burned fiercely" [199] } \\
\text { “... failure of the settlers to protect their homes } \\
\ldots \text {... "Why, then, sleep on in a foolish } \\
\text { insecurity?" [200] }\end{array}$ & {$[199,200]$} \\
\hline 1923, February & $\begin{array}{l}\text { Adelaide Hills: } \\
\text { Morialta to Marble Hill }\end{array}$ & $\begin{array}{l}\text { "about } 1000 \text { acres } \\
\text { of rough country } \\
\text { were laid bare" }\end{array}$ & "...bright glow above the hills" & {$[201]$} \\
\hline 1926, February & $\begin{array}{l}\text { Gawler, Port Gawler, Mt } \\
\text { Crawford, Pewsey Vale }\end{array}$ & & "Black Sunday" & {$[202]$} \\
\hline 1929, March & Mt Lofty Ranges & "Thousands of acres" & & [203] \\
\hline 1930, February & Marble Hill & $\begin{array}{l}\text { "The fire destroyed } \\
\text { about } 100 \text { acres .." }\end{array}$ & “... stringybark country adjoining the house" & {$[204]$} \\
\hline 1931, February & Adelaide Hills & $\begin{array}{c}\text { "Nearly } 300 \text { acres of } \\
\text { scrub country .." }\end{array}$ & $\begin{array}{l}\text { “... near the Governor's residence at Marble } \\
\text { Hill" }\end{array}$ & [205] \\
\hline
\end{tabular}


Table A1. Cont

\begin{tabular}{|c|c|c|c|c|}
\hline Year, Month & Location & Extent & Notes & Sources \\
\hline 1933, February & Adelaide Hills & & "Dense volumes of smoke" & [206] \\
\hline 1934, March & Mt Lofty Ranges & & $\begin{array}{l}\text { "At } 8.30 \text { a.m., the flames were roaring in the gully } \\
\text {..." }\end{array}$ & [207] \\
\hline 1935 & Mt Lofty region & & & [108] \\
\hline 1936, April & Adelaide Hills & & $\begin{array}{l}\text { "threatened the Governor's } \\
\text { residence at Marble Hill" }\end{array}$ & [208] \\
\hline 1938, April & Adelaide Hills & & $\begin{array}{l}\text { “...Tuesday morning. Fanned by a strong east wind } \\
\text { and coming down the ranges, it appeared to } \\
\text { threaten Governor's summer residence”. }\end{array}$ & [209] \\
\hline $\begin{array}{c}\text { 1939, January } \\
10 \\
\end{array}$ & Adelaide Hills & $\begin{array}{l}\text { "several hundred square } \\
\text { miles" }[210]\end{array}$ & $\begin{array}{l}\text { "some of the worst in the State's } \\
\text { history" [210]; } 90 \text { houses were lost [12] }\end{array}$ & {$[12,210]$} \\
\hline 1940, March & Mt Lofty Ranges & & $\begin{array}{l}\text { "An entire gully leaped into blaze with a sudden } \\
\text { change of wind" }\end{array}$ & [211] \\
\hline $\begin{array}{c}\text { 1942, January, } \\
\text { February }\end{array}$ & Mt Lofty, Waterfall Gully & & & [212] \\
\hline January, 1943 & $\begin{array}{l}\text { Rowland's Flat, Lyndoch, } \\
\text { Mount Pleasant, Eden Valley } \\
\text { and Springton areas }\end{array}$ & $\begin{array}{l}\text { "More than } 15 \text { square } \\
\text { miles of scrub country .." }\end{array}$ & Large flocks of sheep lost. & [213] \\
\hline 1944, January & Adelaide Hills & About 500 acres. & & [214] \\
\hline 1948, January & $\begin{array}{c}\text { "... from the north, through the } \\
\text { Mt Lofty ranges to Victor } \\
\text { Harbor ..." }\end{array}$ & & & [215] \\
\hline $\begin{array}{c}\text { 1950, February } \\
\text { [114], April } \\
\text { [216] }\end{array}$ & $\begin{array}{l}\text { Near Eagle on the Hill, } \\
\text { Mt Lofty region }\end{array}$ & $\begin{array}{l}39 \text { square } \\
\mathrm{km}[216]\end{array}$ & $\begin{array}{l}\text { "A scrub fire threatened the viceregal residence at } \\
\text { Marble Hill at } 1 \text { a.m. today" } \\
\text { “... strong breeze ..." [216] }\end{array}$ & $\begin{array}{c}{[114] \text { (p. 54) }} \\
\text { and [216] }\end{array}$ \\
\hline 1951, January & $\begin{array}{l}\text { "Upper Sturt Estate" (Mt Lofty } \\
\text { Ranges?) }\end{array}$ & & Three policemen died. & [114] (p. 54) \\
\hline 1952 & My Lofty region & & & [108] \\
\hline 1955, January & $\begin{array}{c}\text { Gawler to Strathalbyn; } \\
\text { Marble Hill }\end{array}$ & 600 square miles & "most devastating bushfire" & [217] \\
\hline 1957, February & Horsnell's Gully & $>2500$ acres & $\begin{array}{l}\text { "Fire sped up Horsnell's Gully". Burned "orchards, } \\
\text { gardens, houses, scrub and forest" }\end{array}$ & [100] \\
\hline $\begin{array}{l}1958,1959, \\
1960,1961\end{array}$ & Mt Lofty Region & & & [108] \\
\hline 1980, February & Adelaide Hills & $\begin{array}{l}\text { "numerous large } \\
\text { bushfires" }\end{array}$ & Fifty one homes lost & {$[80]$} \\
\hline 1983, February & $\begin{array}{l}\text { Many fires including Cudlee } \\
\text { Creek, Mt Lofty, Kuitpo- } \\
\text { Ashbourne } \\
\end{array}$ & - & $\begin{array}{l}\text { Death of people; loss of plantations, orchards; and } \\
\text { grazing land burned [79]; } 28 \text { killed, } 300 \text { houses lost } \\
{[80]}\end{array}$ & {$[79,80]$} \\
\hline 1985, January & Black Hill & 1500 ha & & [218] \\
\hline 1986, March & Adelaide and Adelaide Hills & $\begin{array}{l}\text { "40 reports of bushfires } \\
\text { in and around the } \\
\text { Adelaide area" }\end{array}$ & & [80] \\
\hline
\end{tabular}


Table A1. Cont.

\begin{tabular}{|c|c|c|c|c|}
\hline Year, Month & Location & Extent & Notes & Sources \\
\hline $\begin{array}{c}1987, \\
\text { November }\end{array}$ & Strathalbyn & 6000 ha & & {$[218]$} \\
\hline 1988, January & Morialta, & & & {$[114](\mathrm{p}$} \\
\hline 7 & Cleland National Park & & & 230) \\
\hline 1995, January & Adelaide Hills & $\begin{array}{c}\text { "hundreds of thousands of hectares } \\
\text { burnt" }\end{array}$ & & {$[80]$} \\
\hline 1996, January & Adelaide Hills & & 5000 people affected & {$[80]$} \\
\hline 1998, March & Adelaide Hills & & & {$[80]$} \\
\hline 1999, May & Mt Lofty Ranges & & $\begin{array}{l}\text { "scrub fire after a burn-off got out of } \\
\text { control" }\end{array}$ & $\begin{array}{c}{[114](\mathrm{p}} \\
279)\end{array}$ \\
\hline $\begin{array}{c}\text { 2000, June } \\
{[\mathrm{sic}]}\end{array}$ & Brownhill Creek & $1000 \mathrm{ha}$ & & [218] \\
\hline $\begin{array}{c}2001, \\
\text { December }\end{array}$ & Hillbank & 350 ha & & [218] \\
\hline 2005, January & Mt Osmond & $120 \mathrm{ha}$ & & {$[218]$} \\
\hline 2007, January & Mt Bold reservoir area & & & {$[88]$} \\
\hline 2013, May & $\begin{array}{c}\text { Cherryville, Basket Range, Mount } \\
\text { Lofty }\end{array}$ & 730 ha & 1 house burned & [219] \\
\hline 2014, January & Eden Valley & $\begin{array}{c}\text { 25,000 ha (including area outside } \\
\text { AMLR) }\end{array}$ & & [218] \\
\hline
\end{tabular}

\section{References}

1. Barnosky, A.D.; Matzke, N.; Tomiya, S.; Wogan, G.O.U.; Swartz, B.; Quental, T.B.; Marshall, C.; McGuire, J.L.; Lindsey, E.L.; Maguire, K.C.; et al. Has the Earth's sixth mass extinction already arrived? Nature 2011, 471, 51-57.

2. Ceballos, G.; Ehlich, P.R. Mammal population losses and the extinction crisis. Science 2002, 296, 904-907.

3. Department of the Environment and Heritage, Australian Government. Threatened Species and Communities Fact Sheet. 2004. Available online: http:/www.environment.gov.au/resource/ threatened-australian-plants-0 (accessed on 10 April 2014).

4. Worboys, G.L., Francis, W.L., Lockwood, M., Eds. Connectivity Conservation Management. A Global Guide; Earthscan: London, UK, 2010.

5. Gill, A.M. Fire and the Australian flora: A review. Aust. For. 1975, 38, 4-25.

6. Gill, A.M. Adaptive responses of Australian vascular plant species to fires. In Fire and the Australian Biota; Gill, A.M., Groves, R.H., Noble, I.R., Eds.; Australian Academy of Science: Canberra, ACT, Australia, 1981; pp. 243-272.

7. Cary, G.J.; Bradstock, R.A.; Gill, A.M.; Williams, R.J. Global change and fire regimes in Australia. In Flammable Australia: Fire Regimes, Biodiversity and Ecosystems in a Changing World; Bradstock, R.A., Gill, A.M., Williams, R.J., Eds.; CSIRO Publishing: Melbourne, VIC, Australia, 2012; pp. 149-169. 
8. Steffen, W.; Hughes, L. The Critical Decade 2013. Climate Change Science, Risks and Responses; Climate Commission Secretariat, Commonwealth of Australia: Canberra, ACT, Australia, 2013.

9. Gill, A.M.; Williams, R.J.; Woinarski, J.C.Z. Fires in Australia's tropical savannas: Interactions with biodiversity, global warming and exotic biota. In Tropical Fire Ecology: Climate Change, Land Use and Ecosystem Dynamics; Cochrane, M., Ed.; Springer: Berlin, Germany, 2009; pp. 113-141.

10. Pearce, K.; Holper, P.; Hopkins, M.; Bouma, W.; Whetton, P.; Hennessy, K.; Power, S. Climate Change in Australia; CSIRO: Melbourne, VIC, Australia, 2007.

11. Steffen, W. The Angry Summer; Climate Commission Secretariat, Commonwealth of Australia: Canberra, ACT, Australia, 2013.

12. Bryant, C. Understanding Bushfire: Trends in Deliberate Vegetation Fires in Australia; Technical Report 27; Australian Institute of Criminology: Canberra, ACT, Australia, 2008.

13. Shu, L.; Tian, X. Fire situation in China. Int. For. Fire News 2002, 26, 9-14.

14. Romero-Calcerrada, R.; Novillo, C.J.; Millington, J.D.A.; Gomez-Jimenez, I. GIS analysis of spatial patterns of human-caused wildfire ignition risk in the SW of Madrid (Central Spain). Landscape Ecol. 2008, 14, doi:10.1007/s10980-008-9190-2.

15. Penman, T.D.; Bradstock, R.A.; Price, O. Modelling the determinants of ignition in the Sydney Basin, Australia: implications for future management. Int. J. Wildland Fire 2013, 22, 469-478.

16. Jollands, M.; Morris, J.; Moffat, A.J. Wildfires in Wales; Report to Forestry Commission Wales; Forest Research: Farnham, Wales, 2011. Available online: http://www.forestry.gov.uk/fr/ wildfiresinwales\#finalreport (accessed on 10 April 2014).

17. Curt, T.; Delcros, P. Managing road corridors to limit fire hazard. A simulation approach in southern France. Ecol. Eng. 2010, 36, 457-465.

18. Cardille, J.A.; Ventura, S.J.; Turner, M.G. Environmental and social factors influencing wildfires in the upper Midwest, United States. Ecol. Appl. 2001, 11, 111-127.

19. Minnich, R.A. California climate and fire weather. In Fire in California's Ecosystems; Sugihara, N.G., van Wagtendonk, J.W., Shaffer, K.E., Fites-Kaufman, J., Thode, A.E., Eds.; University of California Press: Berkeley, CA, USA, 2006; pp. 13-37.

20. Gill, A.M.; Stephens, S.L.; Cary, G.J. The worldwide "wildfire" problem. Ecol. Appl. 2013, 23, 438-454.

21. Department of the Environment, Australian Government. Australia's 15 National Biodiversity Hotspots; Australian Government: Canberra, ACT, Australia, 2006. Available online: http://www.environment.gov.au/topics/biodiversity/biodiversity-conservation/biodiversity-hotspots/ national-biodiversity-hotspots (accessed on 10 April 2014).

22. Guerin, G.R.; Lowe, A.J. Multi-species distribution modelling highlights the Adelaide Geosyncline, South Australia, an important continental-scale arid-zone refugium. Austral Ecol. 2013, 38, 427-435.

23. Lindenmayer, D.B.; Fischer, J. Habitat Fragmentation and Landscape Change: An Ecological and Conservation Synthesis; Island Press: Washington, DC, USA, 2006.

24. Australian Government. Caring for our Country Business Plan 2012-13. Site Investment Guide. Protecting Critical Aquatic Ecosystems. Site: Fleurieu Peninsula Swamps Complex. 2013. 
Available online: http://www.nrm.gov.au/resources/publications/bp-2012-13/pubs/ sig-hevae-fleurieu-peninsula-sa.pdf (accessed on 10 April 2014).

25. Willson, A.; Bignall, J. Regional Recovery Plan for Threatened Species and Ecological Communities of Adelaide and the Mount Lofty Ranges, South Australia 2009-2014; Department of Environment and Heritage: Adelaide, SA, Australia, 2009.

26. Australian Bureau of Statistics. Estimated Resident Population, States and Territories - Greater Capital City Statistical Areas. 2013. Available online: http:/www.abs.gov.au/ausstats/abs@.nsf/ Products/3218.0 2012 Main+Features Main+Features?OpenDocument\#PARALINK1 (accessed on 10 April 2014).

27. Yelland, E.M., Ed.Colonists, Copper and Corn in the Colony of South Australia 1850-51 by an Old Colonist; The Hawthorn Press: Melbourne, VIC, Australia, 1970.

28. Bardsley, D. There is a change on the way-An Initial Assessment of Projected Climate Change Impacts and Adaptation Options for Natural resource Management in the Adelaide and Mt Lofty Ranges Region; Government of South Australia, Department of Water, Land and Biodiversity Conservation: Adelaide, SA, Australia, 2006.

29. Department of Planning and Local Government. The 30-Year Plan for Greater Adelaide. A Volume of the South Australian Planning Strategy; Government of South Australia: Adelaide, SA, Australia, 2010.

30. Bryan, B.A. Reserve selection for nature conservation in South Australia: Past, present and future. Aust. Geog. Stud. 2002, 40, 196-209.

31. Simeon Telfer. South Australian Department of Environment, Water and Natural Resources, Adelaide, SA, Australia. Personal communication, 2014.

32. Williams, M. The Making of the South Australian Landscape. A Study in the Historical Geography of Australia; Academic Press: London, UK, 1974.

33. Australian Bureau of Statistics. Population Projections, Australia, 2012 (base) to 2101, 2013. Available online: http://www.abs.gov.au/ausstats/abs@.nsf/Lookup/3222.0main+features 102012\%20(base)\%20to\%202101 (accessed on 10 April 2014).

34. Sands, D.P.A.; New, T.R. The Action Plan for Australian Butterflies; Environment Australia: Canberra, ACT, Australia, 2002.

35. Tait, C.J.; Daniels, C.B.; Hill, R.S. Changes in species assemblages within the Adelaide Metropolitan area, Australia, 1836-2002. Ecol. Appl. 2005, 15, 346-359.

36. Niesingh, M.; Shackley, A. Revegetation Action Plan. Clonlea Park; A Report for the Town of Gawler Council and the Adelaide and Mount Lofty Ranges Natural Resource Management Board; 2009. Available online: http:/www.gawler.sa.gov.au/webdata/resources/files/ Revegetation_Project_2009_-_2010.pdf (accessed on 10 April 2014).

37. Gammage, B. The Biggest Estate on Earth. How Aborigines Made Australia; Allen and Unwin: Sydney, NSW, Australia, 2011.

38. Gammage, B. The Adelaide District in 1836. In Turning Points: Chapters in South Australian History; Foster, R., Sendziuk, P., Eds.; Wakefield Press: Adelaide, SA, Australia, 2012; pp. 7-23. 
39. Paton, D.C.; Prescott, A.M.; Davies, R.J.-P.; Heard, L.M. The distribution, status and threats to temperate woodlands in South Australia. In Temperate Eucalypt Woodlands in Australia: Biology, Conservation, Management and Restoration; Hobbs, R.J., Yates, C.J., Eds.; Surrey Beatty \& Sons: Chipping Norton, NSW, Australia, 2000; pp. 57-85.

40. Davies, R.J.-P.; Whalen, M.A.; Mackay, D.A.; Taylor, D.A.; Pisanu, P. Does soil seed bank diversity limit post-fire regeneration in small, fragmented, long-unburnt remnants of fire-adapted vegetation? Biol. Cons. 2013, 158, 287-295.

41. City of Salisbury. Urban Forest Biodiversity Program (Undated). Available online: http://www.salisbury.sa.gov.au/Our_City/Environment/Sustainability_and_Climate_Change/Bio diversity_and_Open_Space/Urban_Forest_Biodiversity_Program (accessed on 10 April 2014).

42. Cape Borda to Barossa NatureLink Plan; Government of South Australia: Adelaide, SA, Australia, 2009. Available online: http://www.environment.sa.gov.au/naturelinks/corridors/ Cape_Borda_to_Barossa (accessed on 10 April 2014).

43. Department of Sustainability, Environment, Water, Population and Communities, Australian Government. National Wildlife Corridors Plan: A Framework for Landscape-Scale Conservation; Commonwealth of Australia: Canberra, ACT, Australia, 2012.

44. Adelaide Cemeteries Authority. West Terrace Plan of Management 2013-2018. Enfield Plaza, South Australia, 2013. Available online: http://www.aca.sa.gov.au/Portals/0/Documents/ Annual\%20reports/ACEM\%20997\%20West\%20Terrace\%20Report_full.w.pdf (accessed on 10 April 2014).

45. Shackley, A. Understanding pre-European Adelaide Plains and Foothills Vegetation Associations-Managing Remnants and Recreating Grasslands. 2012. Available online: Understanding_pre-European_Adelaide_plains_and_foothills_vegetation_associations.pdf (accessed on 10 April 2014).

46. Gill, A.M.; Sharples, J.J.; Johnstone, G. Edge effects on between-fire interval in landscape fragments such as fire-prone terrestrial conservation reserves. Biol. Cons. 2014, 169, 54-59.

47. Sumerling, P. The Adelaide Parklands, a Social History; Wakefield Press: Adelaide, SA, Australia, 2011.

48. Long, M. A Biodiversity Survey of the Adelaide Parklands South Australia in 2003; Department of Environment and Heritage: Adelaide, SA, Australia, 2003.

49. Urban Forests Biodiversity Program, Adelaide, Urban Biodiversity Unit, Backyards for Wildlife. Available online: http://www.backyards4wildlife.com.au/ (accessed on 10 April 2014).

50. Mahony, E. The first settlers at Gawler. Proc. R. Geog. Soc. Australasia (South Australian Branch) 1926-1927, 28, 53-82.

51. Ellis, R.W. The Aboriginal inhabitants and their environment. In Natural History of the Adelaide Region; Twidale, C.R., Tyler, M.J., Webb, B.P., Eds.; Royal Society of South Australia: Adelaide, SA, Australia, 1976; pp. 113-120. (From Clarke et al., 2005)

52. Nicholson, P.H. Fire and the Australian Aborigine-An enigma. In Fire and the Australian Biota; Gill, A.M., Groves, R.H., Noble, I.R., Eds.; Australian Academy of Science: Canberra, ACT, Australia, 1981; pp. 55-76. 
53. Benson, J.S.; Redpath, P.A. The nature of pre-European native vegetation in Australia: A critique of Ryan, D.G., Ryan, J.R. and Starr, B.J. (1995) The Australian Landscape-Observations of explorers and early settlers. Cunninghamia 1997, 5, 285-328.

54. Enright, N.J.; Thomas, I. Pre-European fire regimes in Australian ecosystems. Geog. Compass 2008, 2/4, 979-1011.

55. Hately, R. The Victorian Bush. Its "Original and Natural” Condition; Polybractea Press: South Melbourne, VIC, Australia, 2010.

56. Lunt, I.D. Management of remnant lowland grasslands and grassy woodlands for nature conservation: A review. Victor. Nat. 1991, 108, 56-66.

57. Lindenmayer, D.B.; Crane, M.; Michael, D. Woodlands. A Disappearing Landscape; CSIRO Publishing: Melbourne, VIC, Australia, 2005.

58. Garnett, S.T.; Crowley, G.M. The Action Plan for Australian Birds, 2000; Environment Australia: Canberra, ACT, Australia, 2000.

59. Szabo, J.K.; Vesk, P.; Baxter, P.W.J.; Possingham, H.P. Paying the extinction debt: Woodland birds in the Mount Lofty Ranges, South Australia. Emu 2011, 111, 59-70.

60. Suppiah, R.; Preston, B.; Whetton, P.H.; McInnes, K.L.; Jones, R.N.; Macadam, I.; Bathols, J.; Kirono, D. Climate Change under Enhanced Greenhouse Conditions in South Australia. An Updated Report on: Assessment of Climate Change, Impacts and Risk Management Strategies Relevant to South Australia; CSIRO Marine and Atmospheric Research: Melbourne, VIC, Australia, 2006.

61. Mac Nally, R. The lag daemon: Hysteresis in rebuilding landscapes and implications for biodiversity futures. J. Environ. Manag. 2008, 88, 1202-1211.

62. Vesk, P.A.; Nolan, R.; Thomson, J.R.; Dorrough, J.W.; Mac Nally, R. Time lags in provision of habitat resources through revegetation. Biol. Cons. 2008, 141, 174-186.

63. Randall Johnson. South Australian Department of Environment, Water and Natural Resources, Adelaide, SA, Australia. Personal communication, 2014.

64. Lunt, I.D.; Morgan, J.W. The role of fire regimes in temperate lowland grasslands of south-eastern Australia. In Flammable Australia-The Fire Regimes and Biodiversity of a Continent; Bradstock, R.A., Williams, J.E., Gill, A.M., Eds.; Cambridge University Press: Cambridge, UK, 2002; pp. 177-196.

65. Bradstock, R.A., Williams, J.E., Gill A.M., Eds. Flammable Australia. The Fire Regimes and Biodiversity of a Continent; Cambridge University Press: Cambridge, UK, 2002.

66. Hobbs, R. Fire regimes and their effects in Australian temperate woodlands. In Flammable Australia. The Fire Regimes and Biodiversity of a Continent; Bradstock, R.A., Williams, J.E., Gill, A.M., Eds.; Cambridge University Press: Cambridge, UK, 2002; pp. 305-326.

67. Lunt, I.D.; Prober, S.M.; Morgan, J.W. How do fire regimes affect ecosystem structure, function and diversity in grasslands and grassy woodlands of southern Australia. In Flammable Australia. Fire Regimes, Biodiversity and Ecosystems in a Changing World; Bradstock, R.A., Gill, A.M., Williams, R.J., Eds.; CSIRO Publishing: Melbourne, VIC, Australia, 2012; pp. 253-270. 
68. Davies, R.J.-P. Description, distribution, conservation status and weed management of box and buloke grassy woodlands in South Australia. In Temperate Eucalypt Woodlands in Australia: Biology, Conservation, Management and Restoration; Hobbs, R.J., Yates, C.J., Eds.; Surrey Beatty \& Sons: Chipping Norton, NSW, Australia, 2000; pp. 167-189.

69. Fischer, J.; Stott, J.; Zerger, A.; Warren, G.; Sherren, K.; Forrester, R.I. Reversing a tree regeneration crisis in an endangered ecoregion. Proc. Nat. Acad. Sci. USA 2009, 106, 10386-10391.

70. Williams, P.R. Contrasting demographics of tropical savanna and temperate forest eucalypts provide insight into how savannas and forests function-A case study using Corymbia clarksoniana from north-eastern Australia. Austral Ecol. 2009, 34, 120-131.

71. Werner, P.A.; Prior, L.D. Demography and growth of subadult savannah trees: Interactions of life history, size, fire season, and grassy understorey. Ecol. Monog. 2013, 83, 67-93.

72. Williams, R.J.; Cook, G.D.; Gill, A.M.; Moore, P.H.R. Fire regime, fire intensity and tree survival in a tropical savanna in northern Australia. Aust. J. Ecol. 1999, 24, 50-59.

73. Gibbons, P.; Lindenmayer, D.B. Tree Hollows and Wildlife Conservation in Australia; CSIRO Publishing: Melbourne, VIC, Australia, 2002.

74. Gill, A.M. Underpinnings of Fire Management for the Conservation of Biodiversity in Reserves, Revised Edition; Victorian Department of Sustainability and Environment: Melbourne, VIC, Australia, 2009.

75. Lunt, I.D.; Winsemius, L.M.; McDonald, S.P.; Morgan, J.W.; Dehaan, R.L. How widespread is woody plant encroachment in temperate Australia? Changes in woody vegetation cover in lowland woodland and coastal ecosystems in Victoria from 1989 to 2005. J. Biogeog. 2010, $37,722-732$.

76. Bennett, V.A.; Doerr, V.A.J.; Doerr, E.D.; Manning, A.D.; Lindenmayer, D.B; Yoon, H.-J. Causes of reintroduction failure of the brown treecreeper: Implications for ecosystem restoration. Austral Ecol. 2013, 38, 700-712.

77. Anonymous. Black Thursday. The Adelaide Register, 2 February 1912, p. 6.

78. Country Fire Services. The Meadow/Kuitpo fire. The Volunteer Off. J. Ctry. Fire Serv. S. Aust. 1983, 17, 10-13.

79. Bardsley, K.L.; Fraser, A.S.; Heathcote, R.L. The second Ash Wednesday: 16 February 1983. Aust. Geog. Stud. 1983, 21, 129-141.

80. Tait, C. Text Box 107: Bushfires in Adelaide. In Adelaide, Nature of a City; Daniels, C.B., Tait, C.J., Eds.; University of Adelaide: Adelaide, SA, Australia, 2005; pp. 425-427.

81. Teague, B.; McLeod, R.; Pascoe, S. 2009 Victorian Bushfires Royal Commission; Final Report; Victorian Government: Melbourne, VIC, Australia, 2010. Available online: http://www.royalcommission.vic.gov.au/ (accessed on 10 April 2014).

82. Gill, A.M. Fire regimes, biodiversity conservation and prescribed burning regimes. Proc. R. Soc. Vic. 2012, 124, 7-12.

83. Marble Hill. Available online: http://marblehill.com.au/planningandconstruction.html (accessed on 10 April 2014).

84. Adelaide Hills Council. Community Profile. Available online: http://profile.id.com.au/ adelaide-hills/about (accessed on 10 April 2014). 
85. District Council of Mount Barker. Community Profile. Available online: http://profile.id.com.au/ mount-barker/population (accessed on 10 April 2014).

86. Adelaide Hills Council and District Council of Mount Barker. Bushfire Mitigation Plan. Final Plan; Self Published: Adelaide, SA, Australia, 2008.

87. Clarke, P.A.; Gepp, B.; Vickery, F.; Wouters, M.; Henderson, M. Chapter 18. The urban forest 4: Fire, biology and city living. In Adelaide, Nature of a City; Daniels, C.B., Tait, C.J., Eds.; University of Adelaide: Adelaide, SA, Australia, 2005; pp. 422-453.

88. Buckman, S.; Brownlie, K.C.; Bourman, R.P.; Murray-Wallace, C.V.; Morris, R.H.; Lachlan, T.J.; Roberts, R.G.; Arnold, L.J.; Cann, J.H. Holocene palaeofire records in a high-level, proximal valley-fill (Wilson Bog), Mount Lofty Ranges, South Australia. The Holocene 2009, 19, 1017-1029.

89. Naturae Amator. The mountains. South Australian Register, 27 March 1841, p.4.

90. Anonymous. Bush fire near Marble Hill. South Australian Register, 3 February 1897, p.5.

91. Clarke, H.; Lucas, C.; Smith, P. Changes in Australian fire weather between 1973 and 2010. Int. J. Clim. 2013, 33, 931-944.

92. Lucas, C.; Hennessy, K.; Mills, G.; Bathols, J. Bushfire Weather in Southeast Australia: Recent Trends and Projected Climate Change Impacts; Bushfire Cooperative Research Centre and CSIRO: Melbourne, VIC, Australia, 2007.

93. Berry, S.L.; Roderick, M.L. Gross primary productivity and transpiration flux of the Australian vegetation from 1788 to 1988 AD: Effects of $\mathrm{CO}_{2}$ and land use change. Glob. Change Biol. 2004, 10, 1884-1898.

94. King, K.; Cary, G.J.; Gill, A.M.; Moore, A. Implications of changing climate and atmospheric $\mathrm{CO} 2$ for grassland fire in South East Australia: Insights using the GRAZPLAN grassland simulation model. Int. J. Wildland Fire 2012, 21, 695-708.

95. Gill, A.M. Fire, science and society at the rural-urban interface. Proc. R. Soc. Qld. 2009, 115, 153-160.

96. McFarlane, A.C.; Raphael, B. Ash Wednesday: The effects of a fire. Aust. N. Zeal. J. Psychiatry 1984, 18, 341-351.

97. Menadue, B. Tea Tree/Anstey Hill/Gumeracha fire. The Volunteer Off. J. Ctry. Fire Serv. S. Aust. 1983, 17, 14-16.

98. Brodison, K. Effect of Smoke in Grape and Wine Production; Bulletin; Western Australian Department of Agriculture and Food: South Perth, WA, Australia, 2013; p. 4847.

99. Marsh, L. Towards an Understanding of the Adelaide Gully Wind, 4th ed.; Meteorological Notes 175; Bureau of Meteorology: Melbourne,VIC, Australia, 1987; p. 37.

100. Cochrane, G.R.; Burnard, S.; Philpott, J.M. Land use and forest fires in the Mount Lofty Ranges, South Australia. Aust. Geogr. 1962, 8, 143-160.

101. Grace, W.; Holton, I. A Mechanism for Downslope Winds with Special Reference to the Adelaide Gully Wind; Meteorological Notes 179; Bureau of Meteorology: Melbourne, VIC, Australia, 1988.

102. Anonymous. Bush fire in the hills. The Adelaide Advertiser, 24 January, 1906, p.5. 
103. Sharples, J.J.; Gill, A.M.; Dold, J.W. The trench effect and eruptive wildfires: lessons from the King's Cross underground disaster. In Proceedings of the Australasian Fire Authorities Council/Co-Operative Research Centre Conference, Darwin, NT, Australia, 10 September 2010.

104. Viegas, D.X.; Pita, L.P.; Ribeiro, L.; Palheiro, P. Eruptive fire behaviour in past fatal accidents. In Proceedings of the Eighth International Wildland Fire Safety Summit, Missoula, MT, USA, 26-28 April 2005.

105. Sharples, J.J.; McRae, R.H.D.; Wilkes, S.R. Wind-terrain effects on the propagation of wildfires in rugged terrain: fire channelling. Int. J. Wildland Fire 2012, 21, 282-296.

106. Viegas, D.X.; Simeoni, A. Eruptive behaviour of forest fires. Fire Technol. 2011, 47, 303-320.

107. Australian Broadcasting Commission. Flames Approach a Hills Property, 2013. Available online: http://www.abc.net.au/news/2013-05-10/flames-approach-a-hills-propertyjpg/4682470 (accessed on 10 April 2014).

108. Cochrane, G.R. Vegetation studies in forest-fire areas of the Mount Lofty Ranges, South Australia. Ecology 1963, 44, 41-52.

109. Marsden-Smedley, J.B. Prescribed Burning in South Australia: Review of Operational Prescriptions; South Australian Department of Environment and Natural Resources: Adelaide, SA, Australia, 2011.

110. Department for Environment and Heritage, South Australia. Fire Management Plan. Reserves of the Hill Face Zone, Mount Lofty Ranges. 2009-2019; Government of South Australia: Adelaide, SA, Australia, 2009.

111. Heddle, E.M. South African Daisy in the national parks of South Australia. Environ. Cons. 1974, $1,152$.

112. Richards, N.W. Prescribed burning in the southern Mt. Lofty Ranges: How and why is the decision to burn made? Proc. R. Soc. Qld. 2009, 115, 29-35.

113. Department of Environment and Natural Resources, South Australia. Corporate Plan 2012-2014; Government of South Australia: Adelaide, SA, Australia, 2012.

114. Ellis, J-A. Tried by Fire. The Story of the South Australian Country Fire Service; South Australian Country Fire Service: Adelaide, SA, Australia, 2001.

115. Australian Government. Swamps of the Fleurieu Peninsula, South Australia, 2003. Available online: http://www.environment.gov.au/node/14507 (accessed on 10 April 2014).

116. Australian Government. Approved Conservation Advice for the Swamps of the Fleurieu Peninsula Ecological Community. 2013. Available online: http://www.environment.gov.au/ biodiversity/threatened/communities/pubs/031-conservation-advice.pdf (accessed on 10 April 2014).

117. Rebecca Duffield. Conservation Council of South Australia, Adelaide, SA, Australia. Personal communication, 2014.

118. Joosten, H.; Clarke, D. Wise Use of Mires and Peatlands-Background and Principles Including a Framework for Decision-Making; International Mire Conservation Group and International Peat Society; Saarijärven Offset Oy: Saarijärvi, Finland, 2002. Available online: http://www. gret-perg.ulaval.ca/fileadmin/fichiers/fichiersGRET/pdf/Doc_generale/WUMP_Wise_Use_of_ Mires_and_Peatlands_book.pdf(accessed on 10 April 2014). 
119. Wein, R.W. Fire behaviour and ecological effects in organic terrain. In The Role of Fire in Northern Circumpolar Ecosystems; Wein, R.W., MacLean, D.A., Eds.; John Wiley and Sons: Toronto, ON, Canada, 1983; pp. 81-95.

120. Albini, F.A. Wildland fires. Am. Sci. 1984, 72, 590-597.

121. Rein, G.; Cleaver, N.; Ashton, C.; Pironi, P.; Torero, J.L. The severity of smouldering peat fires and damage to the forest soil. Catena 2008, 74, 304-309.

122. Chistjakov, V.I.; Kuprijanov, A.I.; Gorshkov, V.V.; Artsybashev, E.S. Measures for fire prevention on peat deposits. In The Role of Fire in Northern Circumpolar Ecosystems; Wein, R.W., MacLean, D.A., Eds.; John Wiley and Sons: Toronto, ON, Canada, 1983; pp. 259-271.

123. Hungerford, R.D.; Frandsen, W.H.; Ryan, K.C. Ignition and burning characteristics of organic soils. In Fire in Wetlands: A Management Perspective, Proceedings of the 19th Tall Timbers Fire Ecology Conference, Tallahassee, FL, USA, 3-6 November 1993; Cerulean, S.I., Engstrom, R.T., Eds.; Tall Timbers Research Station: Tallahassee, FL, USA, 1995; pp. 78-91.

124. Armstrong, J. Spontaneous Combustion of Forest Fuels: A Review; Information Report FF-X-42; Forest Fire Research Institute: Ottawa, ON, Canada, 1973.

125. Tacconi, L.; Moore, P.F.; Kaimowitz, D. Fires in tropical forests - What is really the problem? Lessons from Indonesia. Mitig. Adapt. Strate. Glob. Change 2007, 12, 55-66.

126. The Guardian. Indonesian President Apologises to Singapore and Malaysia for Forest Fires. 2013. Available online: http://www.guardian.co.uk/world/2013/jun/24/indonesian-president -singapore-malaysia-fires (accessed on 10 April 2014).

127. Chubarova, N.Y.; Prilepsky, N.G.; Rublev, A.N.; Riebau, A.R. A mega-fire event in Central Russia: Fire weather, radiative, and optical properties of the atmosphere, and consequences of subboreal forest plants. In Wildland Fires and Air Pollution. Developments in Environmental Science; Bytnerowicz, A., Arbaugh, M., Riebau, A., Anderson, C., Eds.; Elsevier: Amsterdam, The Netherlands, 2009; Volume 8, pp. 247-264.

128. Global Fire Monitoring Center. Preliminary assessment of the fire situation in western Russia in 2010. Int. For. Fire News 2010, 40, 20-42.

129. Clement, B.M.; Javier, J.; Sah, J.P.; Ross, M.S. The effects of wildfires on the magnetic properties of soils in the Everglades. Earth Surface Process. Landf. 2010, 7, doi:10.1002/esp.2060.

130. Semeniuk, V.; Semeniuk, C.A. Wetland sediments and soils on the Swan Coastal Plain, southwestern Australia: Types, distribution, susceptibility to combustion, and implications for fire management. J. R. Soc. W. Aust. 2005, 88, 91-120.

131. Malcolm Gill. Fenner School of Environment and Society, Australian National University, Canberra, ACT, Australia. Personal communication, 2012.

132. Wark, M.C. Regeneration of some forest and gully communities in the Angahook-Lorne State Park (North-Eastern Otway Ranges) 1-10 years after the wildfire of February 1983. Proc. R. Soc. Victoria 1997, 109, 7-36.

133. Department of Environment and Primary Industries, Victoria. Otway Fire District Planned Burn Program Autumn 2013. Planned Burn: Aireys Inlet-Breakfast Creek 1122 Hectares; Victorian Government: Melbourne, VIC, Australia, 2013. 
134. Malcolm Gill. Fenner School of Environment and Society, Australian National University, Canberra, ACT, Australia. Personal communication, 2009.

135. Thomas, I.; Cullen, P.; Fletcher, M.-S. Ecological drift or stable fire cycles in Tasmania: A resolution? In Altered Technologies. Fire, Climate and Human Influence on Terrestrial Landscapes; Stevenson, J., Prebble, M., Eds.; Australian National University E-Press: Canberra, ACT, Australia, 2010; pp. 341-352.

136. Whinam, J.; Copley, P. A survey of Sphagnum moss in South Australia. Trans. R. Soc. S. Aust. 2011, 135, 55-61.

137. Gott, B. Cumbungi, Typha species: A staple aboriginal food in southern Australia. Aust. Aborig. Stud. 1999, 1, 33-50.

138. Burbidge, A.A.; Roberts, J.D. Sunset Frog Recovery Plan. June 2001-June 2006; Department of Conservation and Land Management Western Australian Threatened Species and Communities Unit: Wanneroo, WA, Australia, 2002.

139. Horizon, C.; O'Connor, N.R.M. A Study of the Mount Lofty Ranges Southern Emu-wren and Fleurieu Peninsula Swamps Recovery Program and how It Contributed to Biodiversity Outcomes in the Adelaide and Mount Lofty Resources Management Region; Performance Story Report; Commonwealth of Australia: Canberra, ACT, Australia, 2008.

140. Abley, A.; Cantono, D.; Pickett, M.; Smith, G.; Stevens, A.; Vale, T. Protecting Fleurieu Peninsula Swamps and the Mount Lofty Ranges Southern Emu-Wren; Conservation Council of South Australia: Adelaide, SA, Australia. Available online: http://www.ccsa.asn.au/files/ emuwren/Protecting\%20FPS\%20MLRSEW\%20booklet\%20100307.pdf (accessed on 5 September 2014).

141. Armstrong, D.M.; Brandle, R. Birds. In A Biological Survey of the Southern Mount Lofty Ranges, South Australia 2000-2001; Armstrong, D.M., Croft, S., Foulkes, J.N., Eds.; South Australian Department of Environment and Heritage: Adelaide, SA, Australia, 2003; pp. 157-176.

142. Department of the Environment, Australian Government. Isoodon obselus obselus-Southern Brown Bandicoot (Eastern). In Species Profile and Threats Database; Australian Government: Canberra, ACT, Australia, 2013. Available online: http:/www.environment.gov.au/cgi-bin/sprat/ public/publicspecies.pl?taxon_id=68050 (accessed on 10 April 2014).

143. Gill, A.M.; Stephens, S.L. Scientific and social challenges for the management of fire-prone wildland-urban interfaces. Environ. Res. Lett. 2009, 4, 1-10.

144. Duncan, M. Response of Orchids to Bushfire: Black Saturday Victoria 2009-Natural Values Fire Recovery Program; Department of Sustainability and Environment: Heidelberg, VIC, Australia, 2012.

145. Jones, D.L. Native Orchids of Australia; Reed Books: Sydney, NSW, Australia, 1988.

146. Joe Quarmby. South Australian Department of Environment, Water and Natural Resources, Adelaide, SA, Australia, 2009.

147. Quarmby, J.P. Recovery Plan for Twelve Threatened Orchids in the Lofty Block Region of South Australia 2010; Department of Environment and Natural Resources, South Australia: Adelaide, SA, Australia, 2010. 
148. Tremblay, R.L.; Perez, M-E.; Larcombe, M.; Brown, A.; Quarmby, J.; Bickerton, D.; French, G.; Bould, A. Dormancy in Caladenia: A Bayesian approach to evaluating latency. Aust. J. Bot. 2009, 57, 340-350.

149. Coates, F.; Lunt, I.D.; Tremblay, R.L. Effects of disturbance on population dynamics of the threatened orchid Prasophyllum correctum D.L. Jones and implications for grassland management in South-Eastern Australia. Biol. Cons. 2006, 129, 59-69.

150. Department of the Environment, Australian Government. Caladenia ovata. In Species Profile and Threats Database; Australian Government: Canberra, ACT, Australia, 2013. Available online: http:/www.environment.gov.au/cgi-bin/sprat/public/spratlookupspecies.pl?name $=$ caladenia + ovata\&searchtype=Wildcard (accessed on 10 April 2014).

151. Department for Environment and Heritage, South Australia. Adelaide and Mount Lofty Ranges Threatened Species Profile. Diuris brevifolia. Short-Leaf Donkey Orchid; South Australian Government: Adelaide, SA, Australia, 2008.

152. Department of the Environment, Australian Government. Thelymitra cyanapicata. In Species Profile and Threats Database; Australian Government: Canberra, ACT, Australia, 2013. Available online: http:/www.environment.gov.au/cgi-bin/sprat/public/publicspecies.pl?taxon_id $=81872 \#$ management_documentation (accessed on 10 April 2014).

153. Department of the Environment, Australian Government. Pterostylis bryophila. In Species Profile and Threats Database; Australian Government: Canberra, ACT, Australia, 2013. Available online: http://www.environment.gov.au/cgi-bin/sprat/public/publicspecies.pl? taxon_id=75722 (accessed on 10 April 2014).

154. Paull, D.J.; Mills, D.J.; Claridge, A.W. Fragmentation of the southern Brown Bandicoot Isoodon obesulus: Unraveling past climate change from vegetation clearing. Int. J. Ecol. 2013, 11,536524 .

155. Long, K. Burrowing bandicoots-An adaptation to life in a fire-prone environment? Aust. Mammal. 2009, 31, 57-59.

156. Thompson, M.B.; Medlin, G.; Hutchinson, R.; West, N. Short-term effects of fuel reduction burning on populations of small terrestrial mammals. Aust. Wildl. Res. 1989, 16, 117-129.

157. Hope, B. Short-term response of the long-nosed bandicoot, Perameles nasuta, and the southern brown bandicoot, Isoodon obesulus obesulus, to low-intensity prescribed fire in heathland vegetation. Wildl. Res. 2012, 39, 731-744.

158. Gepp, B. Box 114. Impact of fires on southern brown bandicoot populations in South Australia. In Adelaide, Nature of a City; Daniels, C.B., Tait, C.J., Eds.; University of Adelaide: Adelaide, SA, Australia, 2005; p. 447.

159. Haby, N.; Long, K. Recovery Plan for the Southern Brown Bandicoot in the Mount Lofty Ranges, South Australia, 2004 to 2009; Department for Environment and Heritage: Adelaide, SA, Australia, 2005.

160. Possingham, H.P.; Gepp, B. Assessment of fire regime options for the Southern Brown Bandicoot Isoodon obesulus in South Australia using population viability analysis. In Proceedings of the Conference on Fire and Biodiversity-The Effects and Effectiveness of Fire Management, Melbourne, VIC, Australia, 8-9 October 1994; Australian Department of the Environment, Sport and Territories: Canberra, ACT, Australia, 1996; pp. 149-153. 
161. Gill, A.M.; Allan, G.; Yates, C. Fire-created patchiness in Australian savannas. Int. J. Wildl. Fire 2003 12, 323-331.

162. Menkhorst, P.W.; Seebeck, J.H. Distribution and conservation status of bandicoots in Victoria. In Bandicoots and Bilbies; Seebeck, J.H., Brown, P.R., Wallis, R.L., Kemper, C.M., Eds.; Surrey Beatty \& Sons: Chipping Norton, NSW, Australia, 1990; pp. 51-60.

163. Rees, M.; Paull, P. Distribution of the southern brown bandicoot (Isoodon obesulus) in the Portland region of South-Western Victoria. Wildl. Res. 2000, 27, 539-545.

164. Bradstock, R.A.; Bedward, M.; Gill, A.M.; Cohn, J.S. Which mosaic? A landscape ecological approach for evaluating interactions between fire regimes, habitat and animals. Wildl. Res. 2005, $32,409-423$.

165. Singh, G.; Kershaw, A.P.; Clark, R. Quaternary vegetation and fire history in Australia. In Fire and the Australian Biota; Gill, A.M., Groves, R.H., Noble, I.R., Eds.; Australian Academy of Science: Canberra, ACT, Australia, 1981; pp. 23-54.

166. Aitken, P.F. Mammals. In Natural History of the South East; Tyler, M.J., Twidale, C.R., Ling, J.K., Holmes, J.W., Eds.; Royal Society of South Australia: Adelaide, SA, Australia, 1983; pp. 127-133.

167. Clarke, M.F. Catering for the needs of fauna in fire management: Science or just wishful thinking. Wildl. Res. 2008, 35, 385-394.

168. Douglas, D. Bushfire Disasters in South Australia with Special Reference to Fires on the Ash Wednesdays of 1980 and 1983; State Government Insurance Commission: Adelaide, SA, Australia, 1983.

169. Department of Environment, Water and Natural Resources. No Species Loss; Government of South Australia: Adelaide, SA, Australia, 2014. Available online: http://www.environment .sa.gov.au/managing-natural-resources/Ecosystem_conservation/No_species_loss (accessed on 13 June 2014).

170. Low, T. The New Nature. Winners and Losers in Wild Australia; Viking: Melbourne, VIC, Australia, 2002.

171. Town of Gawler. Draft Gawler Strategic Directions Report. 2013. Available online: http://www.gawler.sa.gov.au/webdata/resources/files/Draft\%20Strategic\%20Directions\%20Repo rt-2.pdf (accessed on 10 April 2014).

172. Keeley, J.E.; Bond, W.J. Convergent seed germination in South African fynbos and Californian chaparral. Plant Ecol. 1997, 133, 153-167.

173. Gill, A.M.; Zylstra, P. Flammability of Australian forests. Aust. For. 2005, 68, 88-94.

174. Turner, M.S. Conserving Adelaide's Biodiversity: Resources; Urban Forest Biodiversity Program: Adelaide, SA, Australia, 2001.

175. Setterfield, S.A.; Rossiter-Rachor, N.A.; Hutley, L.B.; Douglas, M.M.; Williams, R.J. Turning up the heat: The impacts of Andropogon gayanus (gamba grass) invasion on fire behaviour in northern Australian savannas. Divers. Distrib. 2010, 16, 854-861.

176. Melzer, A.; Carrick, F.; Menkhorst, P.; Lunney, D.; St. John, B. Overview, critical assessment, and conservation implications of Koala distribution and abundance. Cons. Biol. 2000, 14, $619-628$. 
177. Department of the Environment, Australian Government. The Ramsar Convention on Wetlands. Available online: http:/www.environment.gov.au/topics/water/water-our-environment/wetlands/ ramsar-convention-wetlands (accessed on 13 June 2014).

178. Hobbs, R.J.; Arico, S.; Aronson, J.; Baron, J.S.; Bridgewater, P.; Cramer, V.A.; Epstein, P.R.; Ewel, J.J.; Clink, C.A.; Lugo, A.E.; et al. Novel ecosystems: Theoretical and management aspects of the new ecological world order. Global Ecol. Biogeogr. 2006, 15, 1-7.

179. Anonymous. Topics of the day. The South Australian Advertiser, 7 January 1873, p.2.

180. Anonymous. Further particulars. South Australian Register, 1 February 1878, p.5.

181. De Crespigny, M. The Adelaide Establishment: The 1878 Diary of a Provincial Lady of Mount Lofty and Adelaide; Gillingham Printers: Adelaide, SA, Australia, 1987.

182. Anonymous. South Australia. The Hobart Mercury, 15 February 1882, p.2.

183. Anonymous. Fires in the hills. South Australian Register, 24 March 1884, p.7.

184. Bishop, G.C. Stringybark to Orchards. A History of Forest Range and Lenswood; Lenswood Cold Stores Co-Operative Society Ltd.: Lenswood, SA, Australia, 1984.

185. Anonymous. Bush fires. South Australian Register, 26 February 1900, p. 4.

186. Anonymous. Memories of Marble Hill. The Adelaide Register, 21 March 1922, p. 4.

187. Hasluck, A., Ed. Audrey Tennyson's Vice-Regal Days. The Australian letters of Audrey Lady Tennyson to her mother Zacyntha Boyle, 1899-1903; National Library of Australia: Canberra, ACT, Australia, 1978.

188. Anonymous. The bush fires still raging. The Adelaide Advertiser, 11 February 1905, p.7.

189. Anonymous. Bushfires near Echunga. Adelaide Chronicle, 22 March, 1902, p.12.

190. Anonymous. Bush fire at Norton's summit. Adelaide Chronicle, 16 March 1907, p.40.

191. Anonymous. Bush fire at Marble Hill. The Adelaide Register, 25 February 1909, p.5.

192. Anonymous. Fighting the flames. The Adelaide Register, 22 February 1910, p.7.

193. Anonymous. Hot time at Marble Hill. The Adelaide Register, 15 January 1912, p.6.

194. Anonymous. A record blaze. The Adelaide Register, 3 February 1912, p. 16

195. Anonymous. An excited township. The Adelaide Register, 3 February 1912, p. 16.

196. Anonymous. Bush fire near Marble Hill. The Adelaide Register, 24 January 1914, p.17.

197. Anonymous. A fire near Marble Hill. The Adelaide Advertiser, 8 March 1916, p.5.

198. Anonymous. Bush fires in the hills. The Adelaide Register, 12 February 1918, p.5.

199. Anonymous. Progress of hills fire. The Adelaide Register, 5 February 1920, p.7.

200. Anonymous. Hills bush fire. The Adelaide Register, 24 February 1920, p.3.

201. Anonymous. Bush fire above Morialta. Adelaide Daily Herald, 22 February 1923, p.2.

202. Anonymous. The district ablaze. The Gawler Bunyip, 19 February 1926, p.2.

203. Anonymous. Serious fires in Adelaide Hills. Port Pirie Recorder, 13 March 1929, p.1.

204. Anonymous. Governor combats flames-Summer residence threatened. The Melbourne Argus, 19 February 1930, p.7.

205. Anonymous. Bushfires in Adelaide Hills. The Adelaide Register News-Pictorial, 9 February 1931, p.2.

206. Anonymous. Fire near Marble Hill under control. Adelaide News, 27 February 1933, p.5.

207. Anonymous. Fourth day of hills fire. The Adelaide Advertiser, 6 March 1934, p.15.

208. Anonymous. $£ 250$ damage in hills fire. Adelaide News, 4 April 1936, p.1. 
209. Anonymous. Scrub fire at Marble Hill. Governor's residence threatened. Adelaide Chronicle, 7 April 1938, p.47.

210. Foley, J.C. A Study of Meteorological Conditions Associated with Bush and Grass Fires and Fire Protection Strategy in Australia; Commonwealth of Australia Bulletin No. 38; Bureau of Meteorology: Melbourne, VIC, Australia, 1947; p. 234.

211. Anonymous. Bushfires. Gawler Bunyip, 22 March 1940, p.1.

212. Anonymous. Bushfire at Mount Lofty. The Adelaide Advertiser, 16 February 1942, p.3.

213. Anonymous. Bushfires kill sheep. Adelaide Chronicle, 14 January 1943, p.21.

214. Anonymous. Bushfire in hills. Adelaide Chronicle, 27 January 1944, p.23.

215. Anonymous. Worst bushfire toll for years. The Adelaide Advertiser, 23 January 1948, p.1.

216. Anonymous. Fire threat to viceregal home. Adelaide News, 22 April 1950, p.1.

217. Auhl, I. From Settlement to City. A History of Tea Tree Gully 1836-1976; Lynton Publications: Blackwood, SA, Australia, 1978.

218. Country Fire Service, South Australia (CFS). Bushfire History. Available online: http://www.cfs.sa.gov.au/site/about/history/bushfire_history.jsp (accessed on 10 April 2014).

219. Rice, S.; Hegarty, A.; Conlin, T.; Kelton, S. Adelaide Hills bushfire-blaze near Cherryville in Mount Lofty Ranges declared contained. The Adelaide Advertiser, 11 May 2013.

(C) 2014 by the authors; licensee MDPI, Basel, Switzerland. This article is an open access article distributed under the terms and conditions of the Creative Commons Attribution license (http://creativecommons.org/licenses/by/3.0/). 